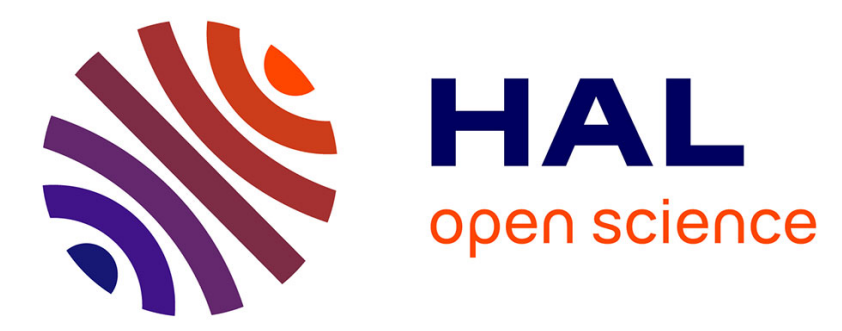

\title{
Innovative photocatalytic luminous textiles optimized towards water treatment: Performance evaluation of photoreactors
}

A. Almansba, A. Kane, N. Nasrallah, R. Maachi, L. Lamaa, L. Peruchon, C. Brochier, I. Béchohra, A. Amrane, A.A. Assadi

\section{To cite this version:}

A. Almansba, A. Kane, N. Nasrallah, R. Maachi, L. Lamaa, et al.. Innovative photocatalytic luminous textiles optimized towards water treatment: Performance evaluation of photoreactors. Chemical Engineering Journal, 2021, 416, pp.129195. 10.1016/j.cej.2021.129195 · hal-03196105

\section{HAL Id: hal-03196105 https://hal.science/hal-03196105}

Submitted on 21 Apr 2021

HAL is a multi-disciplinary open access archive for the deposit and dissemination of scientific research documents, whether they are published or not. The documents may come from teaching and research institutions in France or abroad, or from public or private research centers.
L'archive ouverte pluridisciplinaire HAL, est destinée au dépôt et à la diffusion de documents scientifiques de niveau recherche, publiés ou non, émanant des établissements d'enseignement et de recherche français ou étrangers, des laboratoires publics ou privés. 


\title{
Innovative photocatalytic luminous textiles optimized towards water treatment: Performance evaluation of photoreactors
}

Amira AlmANSBA ${ }^{a, b, c}$, Abdoulaye KANE ${ }^{c}$, Noureddine NASRALLAH ${ }^{a}$, Rachida MAACHI ${ }^{a}$, Lina LAMAA $^{d}$, Laure PERUCHON ${ }^{d}$, Cedric BROCHIER ${ }^{d}$, Imane BÉCHOHRA ${ }^{a}$, Abdeltif AMRANE ${ }^{b}$, Aymen Amine AssADI $\mathrm{b}^{*}$

\author{
aLaboratoire de Génie de la Réaction, Faculté de Génie Mécanique et Génie des Procédés, Université des \\ Sciences et de la Technologie Houari Boumediene, Bab Ezzouar, Alger 16111, Algeria \\ bUniv Rennes, Ecole Nationale Supérieure de Chimie de Rennes, CNRS, ISCR - UMR 6226, F-35000 \\ Rennes, France \\ cUniLaSalle-Ecole des Métiers de l'Environnement, Campus de Ker Lann, 35170 Bruz, France \\ dBrochier Technologies, 90 Rue Frédéric Fays, 69100 Villeurbanne Lyon, France
}

* Corresponding author: A. ASSADI, E-mail: Aymen.assadi@ensc-rennes.fr

\section{Abstract}

The photocatalytic removal of Flumequine (antibiotic) using a luminous textile which served as a support for the $\mathrm{TiO}_{2}$ and a light transmitter through optical fibers was examined in this study. Two configurations of luminous textile were investigated (MonoFace and Double-Face) in terms of compounds degradation and mineralization. Photocatalytic performances of Double-Face configuration were found to be better than the one obtained with Mono-Face. Furthermore, to describe the kinetics of the reaction, the Langmuir-Hinshelwood model was successfully applied and both reaction kinetic and adsorption/desorption equilibrium constants were determined. Double-Face configuration also showed better performances compared to the conventional process in the different 
water matrices tested (ultrapure water, synthetic solution simulating seawater and synthetic hospital wastewater). This configuration was tested for cetirizine (antihistamine) degradation as well, with a satisfying result obtained. Moreover, this technology showed good stability and reusability. On the other hand, the larger size of Double-Face retained its performance at pilot-scale. Finally, the irradiation analyzes showed a good light distribution homogeneity on the textile surface at both laboratory-scale and pilot-scale.

\section{Keywords}

Photocatalysis; Luminous textile; Process intensification; Water matrices; Pilot-scale.

\section{Introduction}

It is well-known that the presence of organic pollutants in wastewater bodies from industrial waste, are harmful to both the environment and human health [1,2]. Most of these pollutants contain stable compounds and possess a poor biodegradability [3]. These contaminants are hardly eliminated from wastewater by conventional methods, such as coagulation, filtration or adsorption [4-6]. These non-destructive techniques consist in a simple transfer of the pollution from one phase to another. Other available water treatment methods such as, biological process and chemical water treatment systems can release toxic by-product pollutants into the environment $[7,8]$.

Since then, it is necessary to tackle this issue by seeking innovative treatment solutions. These innovations can be integrated for example in existing wastewater treatment technologies in order to allow for a complete elimination of persistent pollutants.

Nowadays, heterogeneous photocatalysis with $\mathrm{TiO}_{2}$ under UV-light irradiation is considered as a promising technology. One of the main characteristics of the 
heterogeneous photocatalytic process lies not only in the fact that it allows the degradation of the target molecules, but it also allows the mineralization of by-products [9]. Some of the keys advantages of the $\mathrm{TiO}_{2}$ catalyst are: its low toxicity, low cost, commercial availability and photochemical stability [10]; in addition, it shows the ability of degrading a wide range of organic pollutants. Indeed, it has been already reported by previous researches that suspended $\mathrm{TiO}_{2}$ particles used in photoreactors give high activity due to their high surface area $[11,12]$. However, the semiconductor cannot be easily separated from the treated solution, and hence a recycling process is needed, which is a costly and complicated method to be applied on large scale [13]. Therefore, the immobilization of the photocatalyst became a useful option to avoid this problem [14], but the majority of the designed photocatalytic reactors suffer from poor light penetration, since they involve external light [15]. The main challenge to overcome this bottleneck is to optimize the contact between the light, the catalyst and the pollutant. In fact, since photocatalysis is a heterogeneous process, the adsorption-desorption phenomena of the reagents on the catalyst surface plays a very important role in the photocatalytic process, as demonstrated by Zhou et al, using a simple photocatalyst model for the treatment of substrates with different functional groups, which create different contact interactions with the semiconductor surface [16,17]. Marinangeli and Ollis [18], proposed theoretically, that photoreactors with catalyst-coated optical fibers, could be used as a support for $\mathrm{TiO}_{2}$ photocatalyst and could solve the light transmission problem. Some previous works demonstrated the possibility of using this configuration as an alternative to the wide range of needs for environmental remediation. Optical fibers have however some drawbacks; the main limitation is related to the decrease of light intensity along the axial direction of the coated fiber. Several works were consequently performed to make the light distribution 
homogeneous all along the fiber by varying the thickness and length of the $\mathrm{TiO}_{2}$ deposit, as well as the diameter and number of optical fibers. Despite these efforts, this problem remains persistent [19-21].

In this context, Brochier Technologies has developed a luminous textile, which consists on merging optical and textile fibers. Such configuration is a new technology that, represents a new way to design a high-performance photocatalytic reaction system.

The major innovation of the luminous textile relies on the irradiation from inside by the optical fiber of the immobilized photocatalyst film on the supporting substrate. Luminous textile's lighting is the result of a specific treatment (developed by Brochier Technologies) applied to the optical fiber. It leads to relative homogeneity in light distribution on the textile's surface, increasing that way, the contact between the $\mathrm{TiO}_{2}$, the pollutant and the light source, and hence promoting mass transfer and allowing the exposure of a large catalytic surface to light. The special feature of the luminous textile is the use of LED (Light-Emitting Diode) technology, with consequently a low energy consumption. Furthermore, this technology reduces the photoreactor size. Only few studies have been published regarding the luminous textile, and if that is the case, they were focusing mainly on its characterization aspects $[22,23]$.

In the present study, as a first step we compared the luminous textile performances with a conventional photocatalytic process. Then, a comparative study between two new designs of luminous textile (not previously reported) was performed. A parametric study was performed on the most efficient configuration and tested in different water matrices, then compared to the conventional process. And finally, tested on a pilot-scale with larger luminous textile. 
As model molecules, we selected two commonly used pharmaceuticals compounds which are Flumequine (FLU) and Cetirizine (CET). The FLU is a typical quinolone antibiotic, widely detected in aquatic environments (2.5-50 ng. $\mathrm{L}^{-1}$ ) [24-26]. Previous reports indicated that the release of FLU in the environment is a dramatic concern for aquatic ecosystems, and thus contributes to the development of newly resistant bacteria [27]. Cetirizine (CET) belongs to the piperazine class of antihistamines used to treat allergic rhinitis (high fever), dermatitis, and urticaria. This pollutant is hardly degraded during wastewater treatment [28], and has been frequently reported in surface water samples (4 ng. $\mathrm{L}^{-1}-1.4 \mathrm{mg} \cdot \mathrm{L}^{-1}$ ) [29-31]. To our knowledge, no research work on the depollution of different water matrices (ultrapure water, synthetic solution simulating seawater and synthetic hospital wastewater) using a compactness reactor with a catalyst on doubleface of a luminous textile.

\section{Material and Methods}

\section{$2.1 \quad$ Chemicals}

All chemical reagents were purchased from sigma Aldrich supplier, namely Flumequine $\left(\mathrm{C}_{14} \mathrm{H}_{12} \mathrm{FNO}_{3}, \geq 97.0 \%\right)$, Cetirizine dihydrochloride $\left(\mathrm{C}_{21} \mathrm{H}_{25} \mathrm{CIN}_{2} \mathrm{O}_{3} 2 \mathrm{HCl}, \geq 98.0 \%\right),(\mathrm{HCl}$, $37 \% \mathrm{v} / \mathrm{v}),(\mathrm{NaOH}, 98 \%)$, tetrachloromethane $\left(\mathrm{CCl}_{4}, 99.5 \%\right)$, Tert-Butanol $\left(\left(\mathrm{CH}_{3}\right)_{3} \mathrm{COH}\right.$, purity $>99.5 \%$ ), Ethylenediaminetetraacetic acid (EDTA) (purity $>99 \%$ ), hydrogen peroxide $\left(\mathrm{H}_{2} \mathrm{O}_{2}\right)$. Stock solutions were prepared with ultrapure water (UPW). Characteristics of tap water and synthetic hospital wastewater [32] is summarized in table 1.

Table 1. Characterization of tap water (a) and synthetic hospital wastewater (b). 
(a)

\begin{tabular}{|c|c|}
\hline Parameter & Value \\
\hline $\mathrm{pH}$ & 8.1 \\
\hline Combined chlorine & $0.02 \mathrm{mg}\left(\mathrm{Cl}_{2}\right) \mathrm{L}^{-1}$ \\
\hline Free chlorine & $0.02 \mathrm{mg}\left(\mathrm{Cl}_{2}\right) \mathrm{L}^{-1}$ \\
\hline Total chlorine & $0.04 \mathrm{mg}\left(\mathrm{Cl}_{2}\right) \mathrm{L}^{-1}$ \\
\hline $\begin{array}{c}\text { Staining after simple } \\
\text { filtration }\end{array}$ & $<5 \mathrm{mg}(\mathrm{Pt}) \mathrm{L}^{-1}$ \\
\hline $\begin{array}{l}\text { Nephelometric } \\
\text { turbidity NFU }\end{array}$ & $0.37 \mathrm{NFU}$ \\
\hline Total iron & $39 \mu \mathrm{L} \mathrm{L}^{-1}$ \\
\hline Conductivity at $25^{\circ} \mathrm{C}$ & $522 \mu \mathrm{S} \mathrm{cm}-1$ \\
\hline Total aluminium $\mu g \mathrm{~L}^{-1}$ & $30 \mu \mathrm{g} \mathrm{L}^{-1}$ \\
\hline Ammonium (in $\mathrm{NH}_{4}$ ) & $<0.03 \mathrm{mgL}^{-1}$ \\
\hline Nitrates (in $\mathrm{NO}_{3-\text { ) }}$ & $14.8 \mathrm{mgL}^{-1}$ \\
\hline Nitrates (in $\mathrm{NO}_{2}{ }^{-}$) & $<0.02 \mathrm{mgL}^{-1}$ \\
\hline
\end{tabular}

(b)

\begin{tabular}{|c|c|}
\hline Parameter & Value \\
\hline $\mathrm{pH}$ & $8.0 \pm 0.5$ \\
\hline Turbidity (NTU) & $2 \pm 1$ \\
\hline Conductivity $\left(\mu \mathrm{S} \mathrm{cm}^{-1}\right)$ & $1250 \pm 5$ \\
\hline Suspended solid (mg.L & 0 \\
\hline Chloride (mg.L-1) & $450 \pm 20$ \\
\hline Nitrate $\left(\mathrm{mg} \cdot \mathrm{L}^{-1}\right)$ & $35 \pm 2$ \\
\hline Sulfate $\left(\mathrm{mg} \cdot \mathrm{L}^{-1}\right)$ & $20 \pm 2$ \\
\hline Phosphate (mg.L-1) & $150 \pm 10$ \\
\hline
\end{tabular}

\subsection{Description of the used catalysts}

The $\mathrm{TiO}_{2}$ used in the conventional photocatalysis approach was a mixture of silica, zeolite and $\mathrm{TiO}_{2}$ Millennium PC500 deposited on non-woven cellulose fibers (CP); the thickness of the deposit was $250 \mu \mathrm{m}$. This catalyst (The active surface was equal to $16.210^{-3} \mathrm{~m}^{2}$ ) was purchased from Ahlstrom Company (Alhström 1048).

A finished luminous textile (Fig.1) manufactured by Brochier Technologies Company (UVtex®), were purchased. The technology is a combination of textiles fibers made from 
polyester (Trévira CS TM fibres) and optical fibers core made from polymethyl methacrylate resin, produced by Mitsubishi (PMMA CK-20 Eska ${ }^{\mathrm{TM}}$ fibres) with $480 \mu \mathrm{m}$ of mean diameter covered with $10 \mu \mathrm{m}$ of fluorinated polymer thickness [23]. Specific treatment was performed on the optical fibers in order to let light emission over the whole surface of the luminous textile [33].

Both optical fibers and textile fibers were interlaced together by using Jacquard loom; it means that the textile fibers were disposed horizontally and optical fibers vertically. All the optical fibers were gathered on one side of the lighted textile and connected to a cylindrical connector made of aluminum sealed with silicone (GP-LC7021-0A).

First, the textile was coated by soaking it in a silica Aerodisp W7622 bath, that avoid the attack of $\mathrm{TiO}_{2}$ on the textile. In order to make luminous textile photocatalytically active, it was impregnated in catalyst suspension by soaking $\left(\mathrm{TiO}_{2}\right.$-Degussa $\left.\mathrm{P} 25\right)$ and stirring. The excess of suspension was removed by passing tissue through a micro-rolling mill several times. The luminous textiles were subsequently dried in an oven at $70^{\circ} \mathrm{C}$ for $1 \mathrm{~h}$ [22]. The active surface was a rectangle of $(30 \times 10) \mathrm{cm}^{2}$.

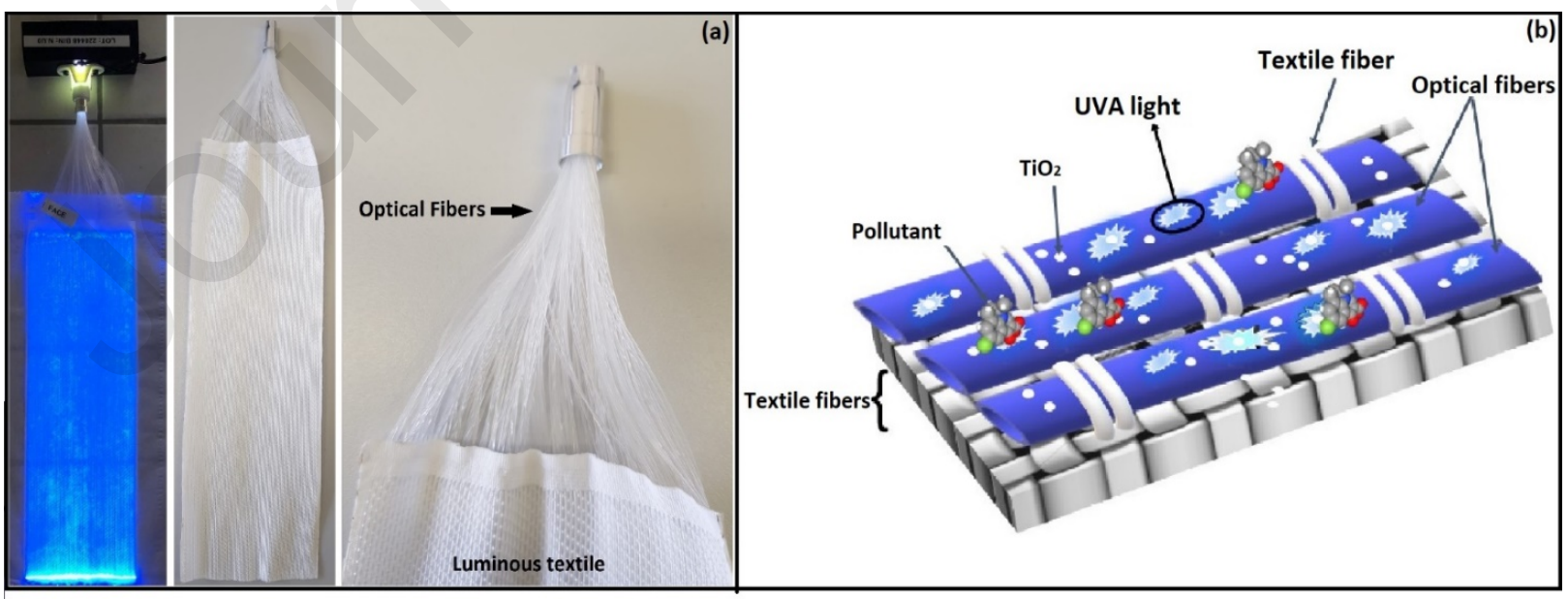

Figure. 1. Images (a) and scheme of the light textile (b). 
Two different luminous textiles were prepared; first one is the "mono-face" (MF) and the second one is "Double-face" (DF). The same number of optical fibers was present in both textile configurations, as well as the amount of $\mathrm{TiO}_{2}$ deposited; the only difference was the distribution of optical fibers. Regarding the DF, optical fibers were distributed on its two sides unlike the MF where it was present on one side only.

In the pilot-scale system, a larger size of DF luminous textile was produced $\left(80 \times 10 \mathrm{~cm}^{2}\right)$ using the same method, with the same catalyst density.

\subsection{Characterization of the luminous textile}

\subsubsection{SEM/EDX analysis}

The analysis of the surface by SEM/EDX (Scanning electron microscopy-energy dispersive spectroscopy X-ray diffraction technique) is a completely accepted method to provide informations about the morphology, topology and structure of the sample [34]. The combination with the EDX technique allows to determine the elemental composition of its surface [34].

Indeed, SEM/EDX analysis provided an enlarged view of the luminous textile sample showing the entanglement between the textile fibers and the optical fibers forming a tying point (Fig.2-a), this analysis also shows defects present on the optical fibers surface inducing a loss of light. The SEM/EDX method revealed the different elements of the luminous textile like: titanium (4.86 Wt. \%), carbon (16.56 Wt. \%) and oxygen (54.68 Wt. \%), which were also previously found in cotton $\mathrm{TiO}_{2}$ support [35]. To these elements' fluorine can be added (17.48 Wt.\%) since the optical fibers cladding is made of fluoropolymer. 
Aluminum (0.14 Wt.\%) was a residual compound of the mechanical treatment of the optical fibers, and silicon (6.05 Wt.\%) corresponded to the silica Aerodisp W7622 deposit.

Moreover, figure 2-c shows a uniform Ti distribution in both optical and textile fibers. The same observation was made by Indermühle et al. when luminous textile was coated by using $\mathrm{TiO}_{2}$ sols [36]. These authors also observed an inhomogeneous distribution of $\mathrm{Ti}$ when coting was done using $\mathrm{TiO}_{2}$ powder, indeed, in this case $\mathrm{TiO}_{2}$ powder was mainly located on the light emission zones in the form of clusters visible on optical fibers and binding points.

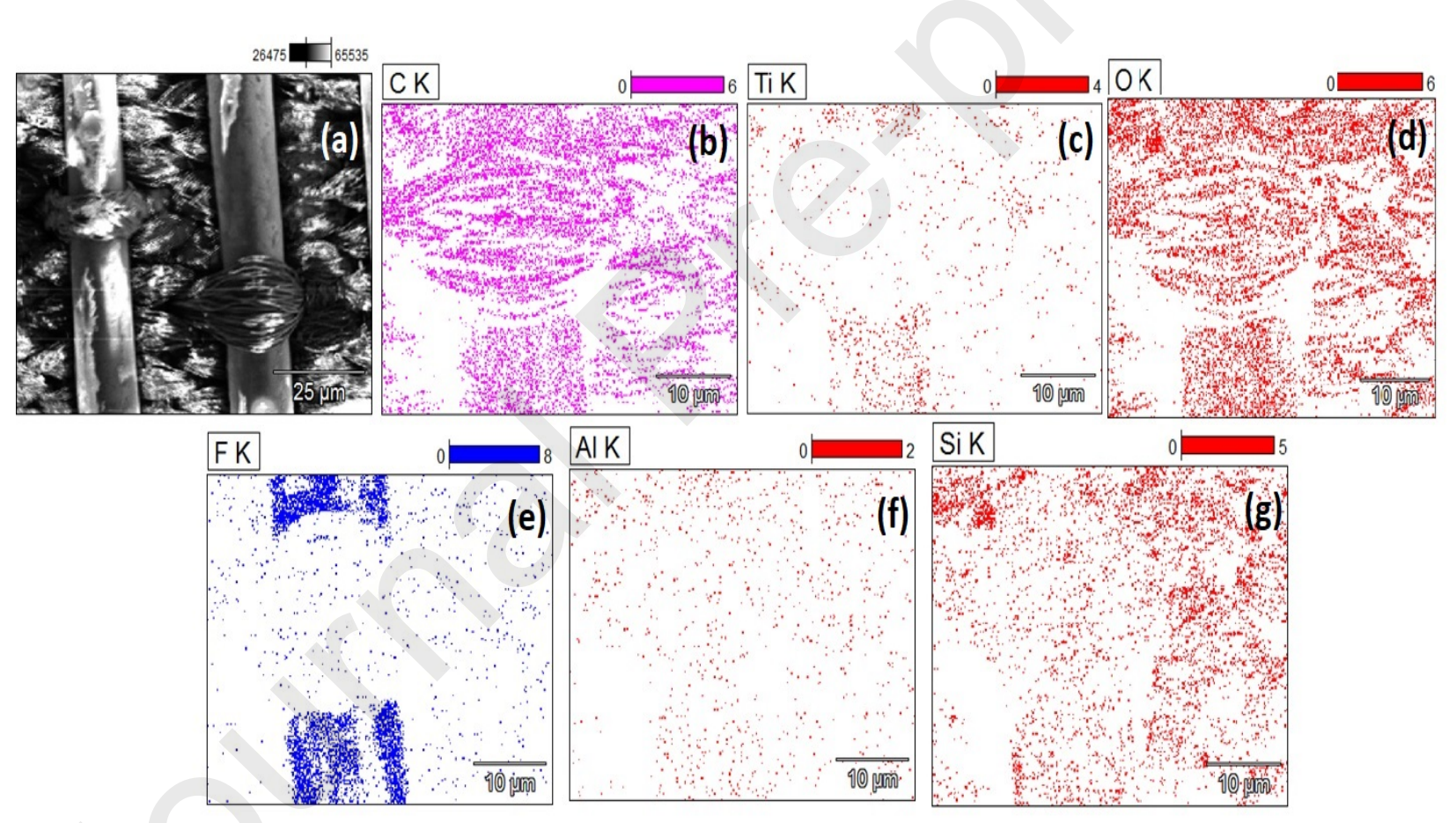

Figure. 2. SEM image (a) and EDX analysis of: $C(b), T i(c), O(d), F(e), A l(f), S i(g)$, for luminous textile.

\subsection{2 $\mathrm{TiO}_{2}$ deposit measurement}

The quantification of $\mathrm{TiO}_{2}$ distribution over the textile surface was evaluated by ICP-OES analysis (Inductively Coupled Plasma with an Optical Emission Spectrometer). The 
luminous textile samples of $6 \mathrm{~cm}^{2}$ were melted with lithium tetraborate and after a heating step, the residue was dissolved in hydrochloric acid. The solutions obtained was sprayed into the heart of a plasma at high temperatures, the atomic vapor produced was analyzed with an optical emission spectrometer (OES) [36]. The catalyst quantity on the textile surface was equal to $12 \mathrm{~g}_{\mathrm{TiO} 2} / \mathrm{m}^{2}$.

\subsubsection{Light distribution measurements}

In order to evaluate the light distribution after the deposition of the $\mathrm{TiO}_{2}$ on the textiles surface, irradiance measures were made by a spectrometer GL SPECTIS 1.0 UV-VIS on both sides of the double-face (DF) used in laboratory-scale and pilot-scale on different points of the textiles (Fig.3).

(a)
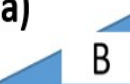

A

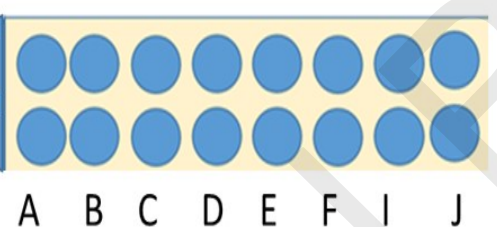

A $\quad B \quad C \quad D \quad E$ F I I

(b)

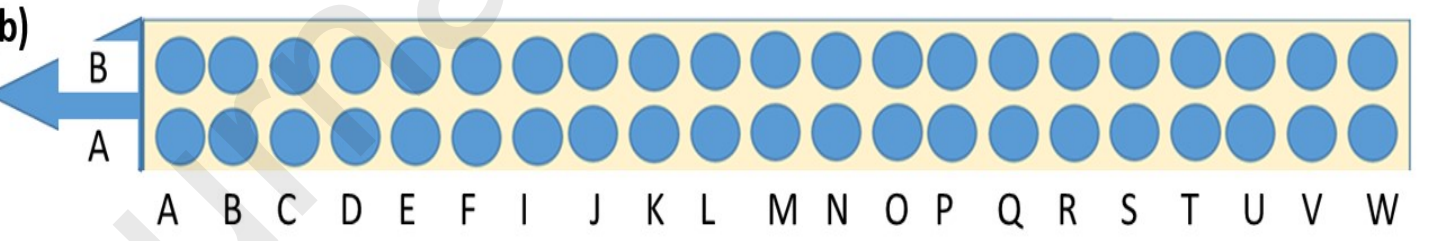

Figure. 3. The irradiance measurement points on the textile at the laboratory-scale (a), and at the pilotscale (b) after $\mathrm{TiO}_{2}$ deposition 
Table 2. The irradiance values measured at several points on the two faces of the DF at laboratory-scale (a), and pilot-scale (b) after $\mathrm{TiO}_{2}$ deposition.

\begin{tabular}{|c|c|c|c|c|}
\hline (a) & & & & \\
\hline & \multicolumn{2}{|c|}{ Face 1} & \multicolumn{2}{|c|}{ Face 2} \\
\hline $\begin{array}{l}\text { Irradiance } \\
\left(\mathrm{mW} / \mathrm{m}^{2}\right)\end{array}$ & A & B & A & B \\
\hline $\mathbf{A}$ & $2054 \pm 10$ & $2147 \pm 15$ & $815 \pm 50$ & $1328 \pm 25$ \\
\hline B & $1698 \pm 15$ & $2068 \pm 20$ & $771 \pm 60$ & $1600 \pm 20$ \\
\hline C & $1455 \pm 11$ & $1775 \pm 25$ & $1395 \pm 11$ & $1647 \pm 15$ \\
\hline D & $1079 \pm 9$ & $1768 \pm 10$ & $1303 \pm 10$ & $1554 \pm 18$ \\
\hline E & $1677 \pm 12$ & $1471 \pm 9$ & $1236 \pm 15$ & $1477 \pm 10$ \\
\hline $\mathbf{F}$ & $1699 \pm 23$ & $1416 \pm 15$ & $1367 \pm 18$ & $1518 \pm 22$ \\
\hline I & $1693 \pm 17$ & $1389 \pm 7$ & $1226 \pm 15$ & $1184 \pm 15$ \\
\hline $\mathbf{J}$ & $1544 \pm 23$ & $1280 \pm 13$ & $1167 \pm 10$ & $1185 \pm 20$ \\
\hline $\begin{array}{l}\text { Average } \\
\left(\mathrm{mW} / \mathrm{m}^{2}\right)\end{array}$ & & $638.3125 \pm 15$ & & $1298.3125 \pm 21$ \\
\hline
\end{tabular}

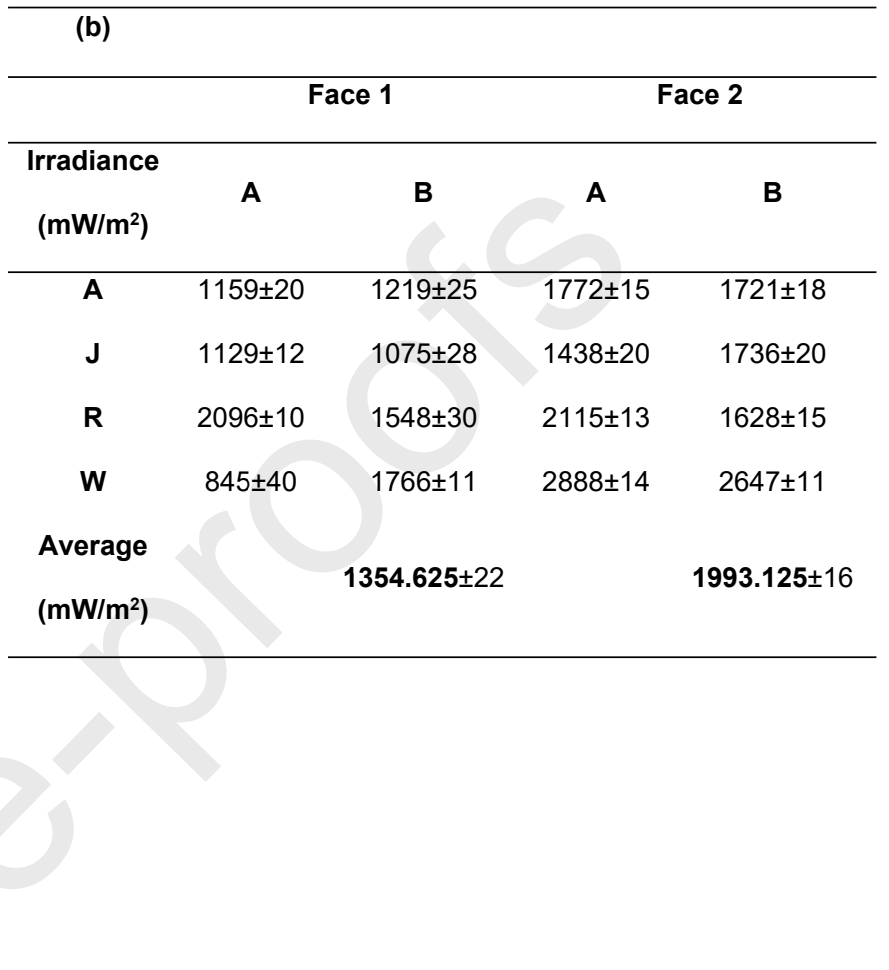

Table 2 shows that the luminous textile technology provided a relatively uniform light distribution over the entire length of its surface. As shown in table 2-b, the textile retained this property even when the size of the luminous textile was increased.

It has been previously reported that due to the difference between the refractive index of the optical fiber and the catalyst, the light is refracted at fiber's surface instead of being totally reflected inside it [37-39]. Furthermore, the light refracted is either transmitted in the surrounding phase or absorbed by the catalyst [40]. Therefore, in order to determine the light energy absorbed by $\mathrm{TiO} 2$, the measurements of the emitted light irradiance by the luminous textile were performed before and after the deposition of the catalyst and carried out at 16 different points on each face of both luminous textile configurations to 
study the UV light distribution on the luminous textile by taking in consideration the refracted light intensity. The difference between the average of these irradiances (with and without catalyst deposition) (Table. 3) corresponds to the TiO2 light absorption, which was calculated according to the Equation 1 reported in previous studies $[23,36,41]$.

Absorbance $=$ Irradiance $($ before $\mathrm{TiO} 2$ coating $)-$ Irradiance (After TiO2 coating)

Table 3. $\mathrm{TiO}_{2}$ absorbance measurements for the double-face (DF) and the mono-face (MF) luminous textiles.

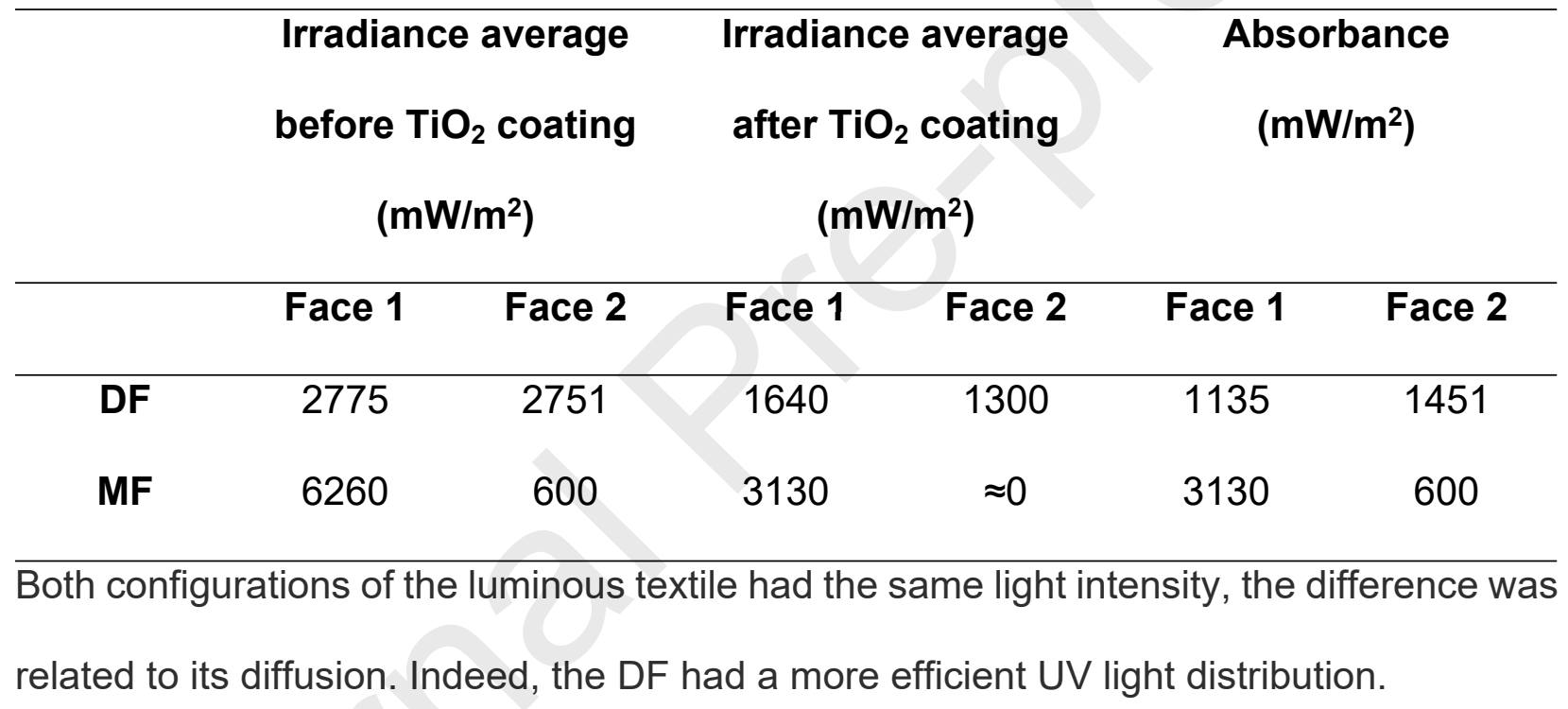

\subsection{Photocatalytic experiments}

The experiments of classical photocatalysis using cellulose paper were conducted in a conventional photoreactor with a central UVA lamp 30 W (Phillips PL-L24W/10/4P) with the emission peak centered at $365 \mathrm{~nm}$, this one was disposed in a transparent sleeve quartz glass tube and immersed in the photoreactor (Fig.4-b).

A graduated cylinder made of borosilicate glass was used as a reactor vessel for luminous textiles experiments at the laboratory-scale. The reactor was filled with $600 \mathrm{~mL}$ of aqueous 
solution and different initial pollutant concentrations at room temperature. A peristaltic pump operating at a flow rate of $87 \mathrm{~mL} \mathrm{~min}^{-1}$ and a magnetic stirrer at $60 \mathrm{rpm}$ were used to recirculate and homogenize the medium (Fig.4-a). The light intensity of MF and DF were $3.1 \mathrm{~W} . \mathrm{m}^{-2}$ and $2.9 \mathrm{~W} . \mathrm{m}^{-2}$, respectively.

The surface of the luminous textile used at the pilot-scale was three times larger than the one used at the laboratory-scale. However, there was no big difference between their luminous intensities; it was $3.3 \mathrm{~W} \cdot \mathrm{m}^{-2}$ in the case of the pilot-scale reactor. The experiments were carried out in a recirculating annular reactor consisting of two concentric Pyrex tubes (Fig.4-c and 4-d), operating continuously and supplied with $2 \mathrm{~L}$ of polluted solution, at a flow rate of $0.65 \mathrm{~m}^{3} / \mathrm{h}$.

Regeneration of the luminous textile was performed under UVA and by stirring in water after each photocatalytic experiment. The textile regeneration duration used at laboratory and pilot scales were about 90 min and 120 min, respectively. 


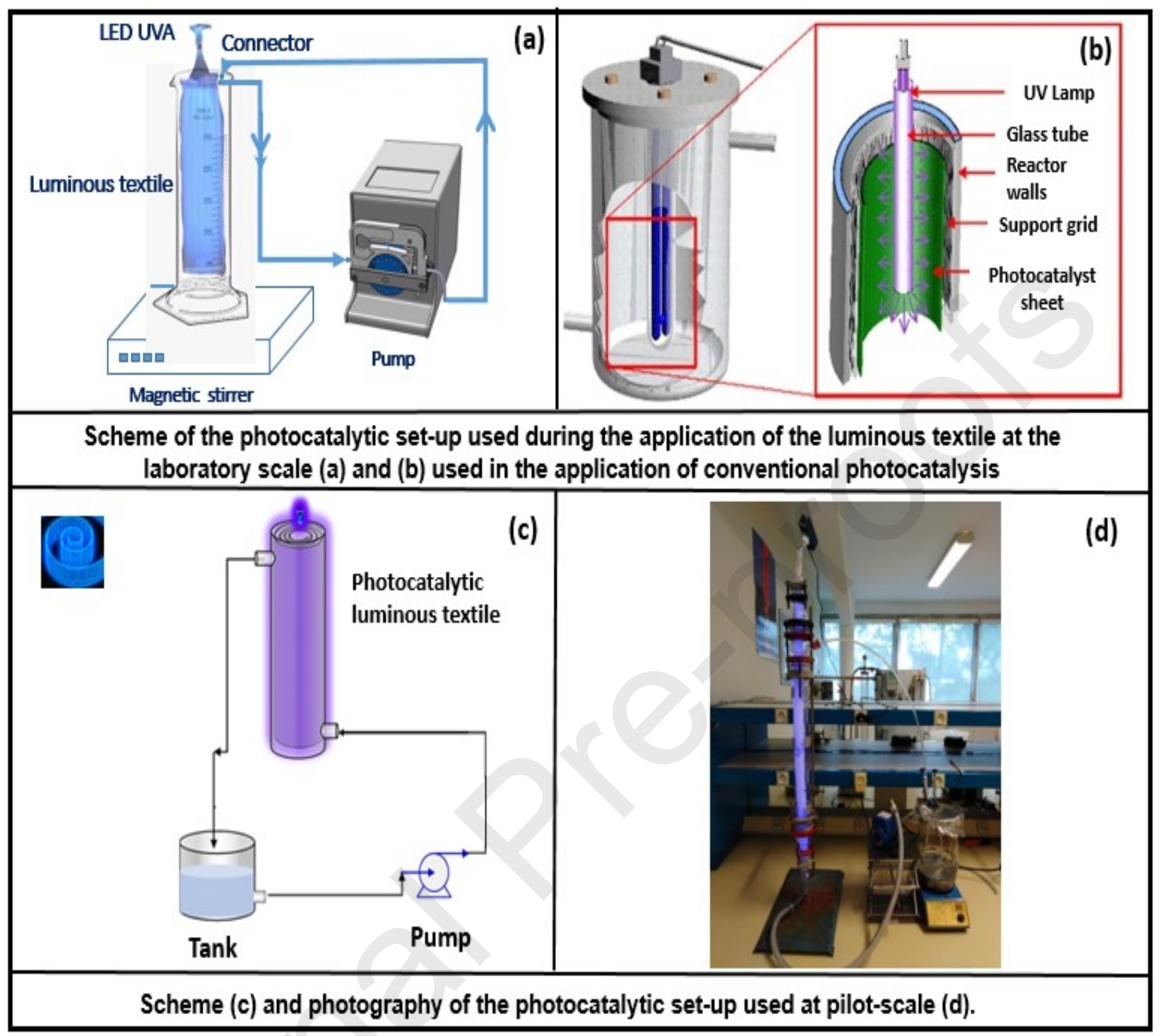

Figure 4. The photocatalytic set-ups used during this study.

The luminous textile was introduced in the reactor and the UV irradiation was delivered by an LED source directly connected to the fabric (centered emission at $365 \mathrm{~nm}$ ). Before the light irradiation, the solution was kept in the dark for $1 \mathrm{~h}$, in order to reach an adsorption-desorption equilibrium between the pollutant and the photocatalyst. The $\mathrm{pH}$ of the solutions was checked along the experiments and adjusted by $\mathrm{HCl}$ or $\mathrm{NaOH}$. 
At regular time intervals, samples were filtered using $0.45 \mu \mathrm{m}$ PTFE Millipore syringe filters before analysis. Aqueous concentrations of the pollutants were measured at a wavelength of $247 \mathrm{~nm}$ for FLU and $231 \mathrm{~nm}$ for CET, by a Shimadzu UV-1800 UV-vis spectrophotometer using quartz cell.

Degradation efficiency (\%) was estimated using the Equation 2.

$$
\eta(\%)=\left(\frac{\mathrm{C} 0-\mathrm{Ct}}{\mathrm{C} 0}\right) \times 100
$$

$\mathrm{C}_{0}$ and $\mathrm{C}_{\mathrm{t}}$ are the initial FLU concentration and its concentration at time $\mathrm{t}$, respectively.

The kinetic analysis of pollutant degradation was carried out using Equation 3

$$
\operatorname{Ln}\left(\frac{\mathrm{Ct}}{\mathrm{C} 0}\right)=k a p p \cdot t
$$

where kapp is the apparent kinetic constant $\left(\mathrm{h}^{-1}\right) ; \mathrm{t}$ is the reaction time, $\mathrm{h}$

The (TOC) was determined using a TOC Analyzer (Shimadzu TOC-VCSH) and the yield was calculated according to the Eq. (4)

$$
\text { mineralization yield }(\%)=\left(\frac{\mathrm{TOC} 0-\mathrm{TOCt}}{\mathrm{TOC} 0}\right) \times 100
$$

$\mathrm{TOC}_{0}$ and $\mathrm{TOC}_{\mathrm{t}}$ are the initial Total Organic Carbon and the Total Organic Carbon at time t, respectively.

In order to make the comparison between the different materials studied, the use of the degradation constant is not the best option, because it does not take into account the number of photons driving it [34]. To overcome this problem, the use of apparent quantum yield (which correspond to a lower limits of the quantum yield) as a performance indicator 
of the photocatalytic material is more appropriate [34]. The apparent quantum yield which based on incident photons was calculated at a precise wavelength according to Equation 5.

$$
A Q Y(\%)=\frac{R_{s}}{I_{0}(\lambda)} \times 100
$$

Where $R_{S}\left(\mathrm{~mol}_{\mathrm{L}}{ }^{-1} \mathrm{~S}^{-1}\right)$ is the transformation rate of the FLU; AQY is the apparent quantum yield of reactant loss at the irradiation wavelength $(\lambda=365 \mathrm{~nm})$ and $\mathrm{I}_{0}$ (Einstein. $L^{-1} s^{-1}$ ) is the effective photon flux which was obtained after correcting the actinometric measurement by convoluting the ferrioxalate spectrum [42].

The photocatalytic reaction kinetics of many organic compounds has been represented using the Langmuir-Hinshelwood model (Eq.6), which takes into account the contribution of adsorption properties of substrate on the photocatalyst surface and photocatalytic reactions kinetic $[43,44]$. Indeed, the transformation of these substrates, which are adsorbed on the catalyst surface during the process, leads to a variations in their concentration; and Langmuir-Hinshelwood $(\mathrm{L}-\mathrm{H})$ model takes in consideration these phenomena [45].

$$
r_{0}=-\frac{\mathrm{d} C_{0}}{\mathrm{dt}}=\frac{k_{L-H} K_{L} C_{0}}{1+K_{L} C_{0}}
$$

Where $r_{0}\left(\mathrm{mg} \cdot \mathrm{min}^{-1} \cdot \mathrm{L}^{-1}\right)$ is the initial reaction rate, $k_{L-H}\left(\mathrm{mg} \cdot \mathrm{min}^{-1} \cdot \mathrm{L}^{-1}\right)$ is the apparent $\mathrm{L}-\mathrm{H}$ rate and $K_{L}\left(\mathrm{~L}_{\mathrm{mg}} \mathrm{mg}^{-1}\right)$ is the adsorption/desorption equilibrium constant.

\section{Results and discussion}


Our study started with a comparison between the performance of the luminous textile and the cellulosic paper (CP). The effect of different parameters on the luminous textile were then examined, such as, $\mathrm{pH}$, design of luminous textile, initial pollutant concentration, impact of oxidant addition, water matrix. Moreover, for each individual pollutant, the performances of the double-face configuration were also tested and compared (FLU and CET). In addition, the reusability of the luminous textile was also examined. Finally, a pilotscale application was carried out, and the results obtained are being discussed in this work.

The degradation process was followed by monitoring both the pollutant disappearance (degradation) and the mineralization degree.

\subsection{Comparison between the photocatalytic performances of the conventional process and the MF luminous textile}

The first experiment on the luminous textile was conducted to compare its photocatalytic performance and at the same time its energy consumption to the conventional method of photocatalysis using cellulose paper as support for $\mathrm{TiO}_{2}$. The amount of catalyst deposited on the two supports was identical and equal to $0.36 \mathrm{~g}$. The MF was selected for this comparison in terms of apparent quantum yield (Eq. 5), at $20 \mathrm{mg}^{-\mathrm{L}^{-1}}$ initial pollutant amount. $\mathrm{R}^{2}$ (correlation coefficient) of the initial slope was equal to 0.989 for MF and 0.976 for $\mathrm{CP}$.

As shown in table 4, the luminous textile was much more efficient than the CP in terms of

FLU apparent quantum yield; this can be justified by a better penetration of light in the case of the luminous textile because the catalyst was in direct contact with the light source. 
This is the main obstacle, which usually slows down the traditional processes of photocatalysis and this can be avoidable by using this new technology. The other advantage was the lower energy consumption; in fact, the light intensity of the MF and the lamp used with CP were $9.310^{-2} \mathrm{~W}$ and $30 \mathrm{~W}$, respectively.

In view of these very encouraging and promising results, a study was undertaken on this innovative process in order to improve its performance.

Table 4. Comparison between the photocatalytic performances of MF and CP in terms of apparent quantum yield of FLU at $365 \mathrm{~nm}$; pH=6.5; [FLU]o = $20 \mathrm{mg} \cdot \mathrm{L}^{-1} ; \Phi(\mathrm{MF})=9.310^{-2}$ $\mathrm{W} ; \Phi(C P)=30 \mathrm{~W}$; reaction volume $=600 \mathrm{~mL}$.

\section{CP MF luminous textile}

\section{Apparent}

quantum yield

$3 \pm 1$

$21 \pm 2$

$(\%)$

\subsection{Effect of $\mathrm{pH}$}

The $\mathrm{pH}$ plays a key role in the photocatalytic reaction. Consequently, the effect of $\mathrm{pH}$ on the degradation rate was studied at three $\mathrm{pH}$ values $(3,6.5$ and 10$)$ with mono-face configuration $\left(R^{2} \geq 0.988\right)$. $\mathrm{pH}$ influence is related to the behavior of the extent of FLU ionization characterized by the acid ionization constant ( $\mathrm{pKa})$, and the superficial charge of the catalyst described by the point of zero charge (PZC).

Previous reports have indicated that the PZC of Degussa P25 is 6 [46], and the pKa of FLU is 6.27 [47]. At $\mathrm{pH}<6(\mathrm{pH}=3)$ the surface of $\mathrm{TiO}_{2}$ is therefore positive and the $\mathrm{FLU}$ is neutral. Similarly, the surface of the catalyst and FLU are negatively charged at $\mathrm{pH}>\mathrm{pzc}$ $(\mathrm{pH}=10)$, causing a repulsion reducing the affinity between them. As seen in figure $5, \mathrm{k}_{\mathrm{app}}$ 
was the lowest at basic $\mathrm{pH}$, namely $10\left(10.2 \times 10^{-2} \mathrm{~h}^{-1}\right)$. Indeed, the charges of both $\mathrm{TiO}_{2}$ and FLU surfaces were the same. Therefore, a $\mathrm{pH}$ of 6.5 was selected for the following experiments in order to get closer to real wastewater conditions.

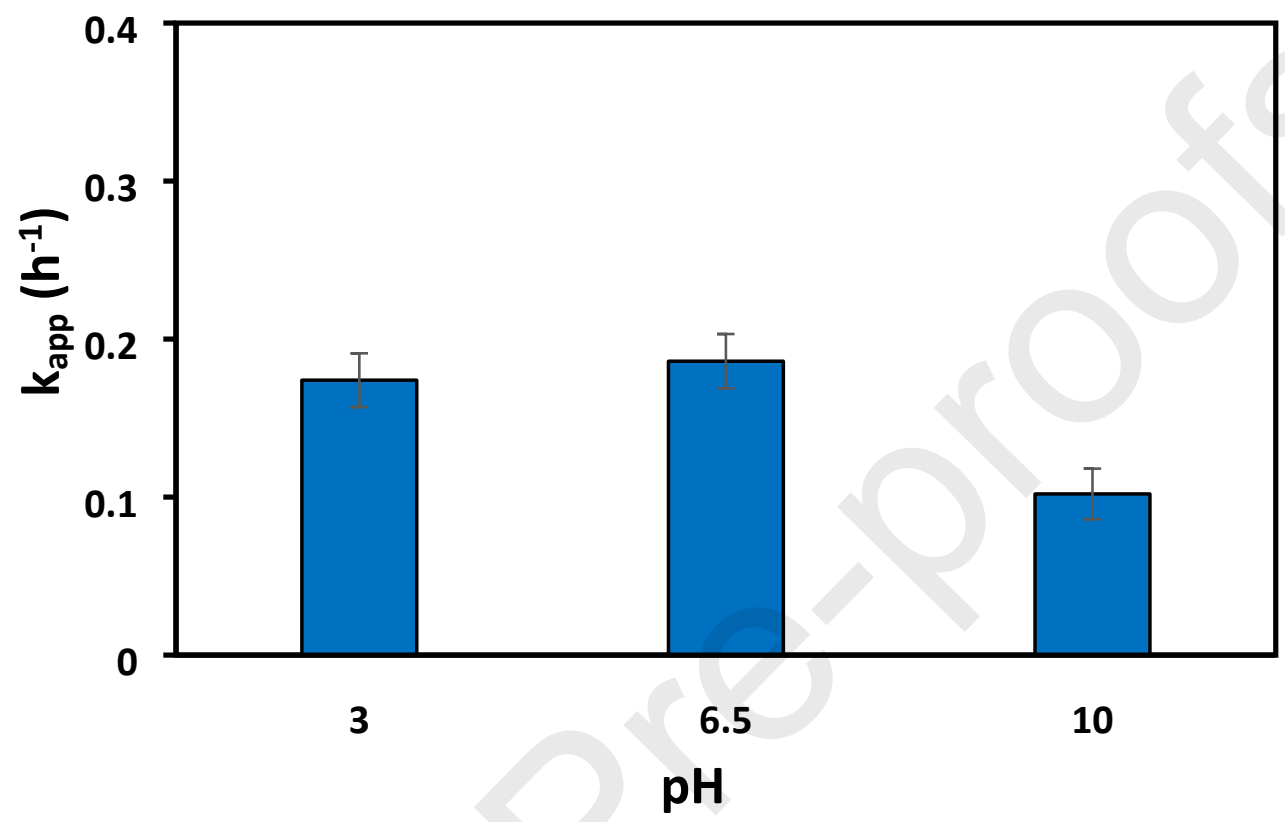

Figure 5. Pseudo-first-order rate constant $\left(k_{a p p}, h^{-1}\right)$ of FLU during 110 min of photocatalytic reaction at different $\mathrm{pH}(3,6.5,10)$ with $[F L U]_{o}=20 \mathrm{mg} \cdot \mathrm{L}^{-1}$; and MF configuration; reaction time $=110$ min; reaction volume $=600 \mathrm{~mL}$.

\subsection{Design of the luminous textile (Comparison of the photocatalytic performances between the MF and DF)}

The final degradation efficiencies and mineralization yields obtained after 330 min using the two luminous textiles implemented under the same experimental conditions are displayed in Fig.6 for the various initial FLU concentrations.

In order to evaluate the FLU mineralization, the TOC removal yields in both textile configurations were determined. The obtained results confirmed the trend observed for 
the pollutant degradation (Fig.6). Indeed, in all cases, the use of DF leads to a higher mineralization yield than MF. It is worth noting that both the degradation efficiency and the level of mineralization decreased when the initial FLU concentration increased.

The highest degradation efficiency and mineralization yields were $93 \%$ and $62 \%$, respectively for $5 \mathrm{mg} \cdot \mathrm{L}^{-1}$ initial FLU amount obtained with the DF configuration (Fig.6). This improvement might be explained by the greater catalytic area exposed to light in the case of DF, due to the distribution of optical fibers on its two faces. Whereas for the MF, the $\mathrm{TiO}_{2}$ on the non-luminous side is not well lighted. A higher exposition of catalytic area to light means a higher production of electron-hole pairs (i.e., at [FLU] $]_{0}=20 \mathrm{mg} \cdot \mathrm{L}^{-1}$, the degradation efficiency was $67 \%$ for DF and only $37 \%$ for MF). Therefore the DF which led to a better performances than MF, was selected for the following experiments in the presence of an initial FLU concentration of $20 \mathrm{mg} \cdot \mathrm{L}^{-1}$ in order to define performances limits of the luminous textile.

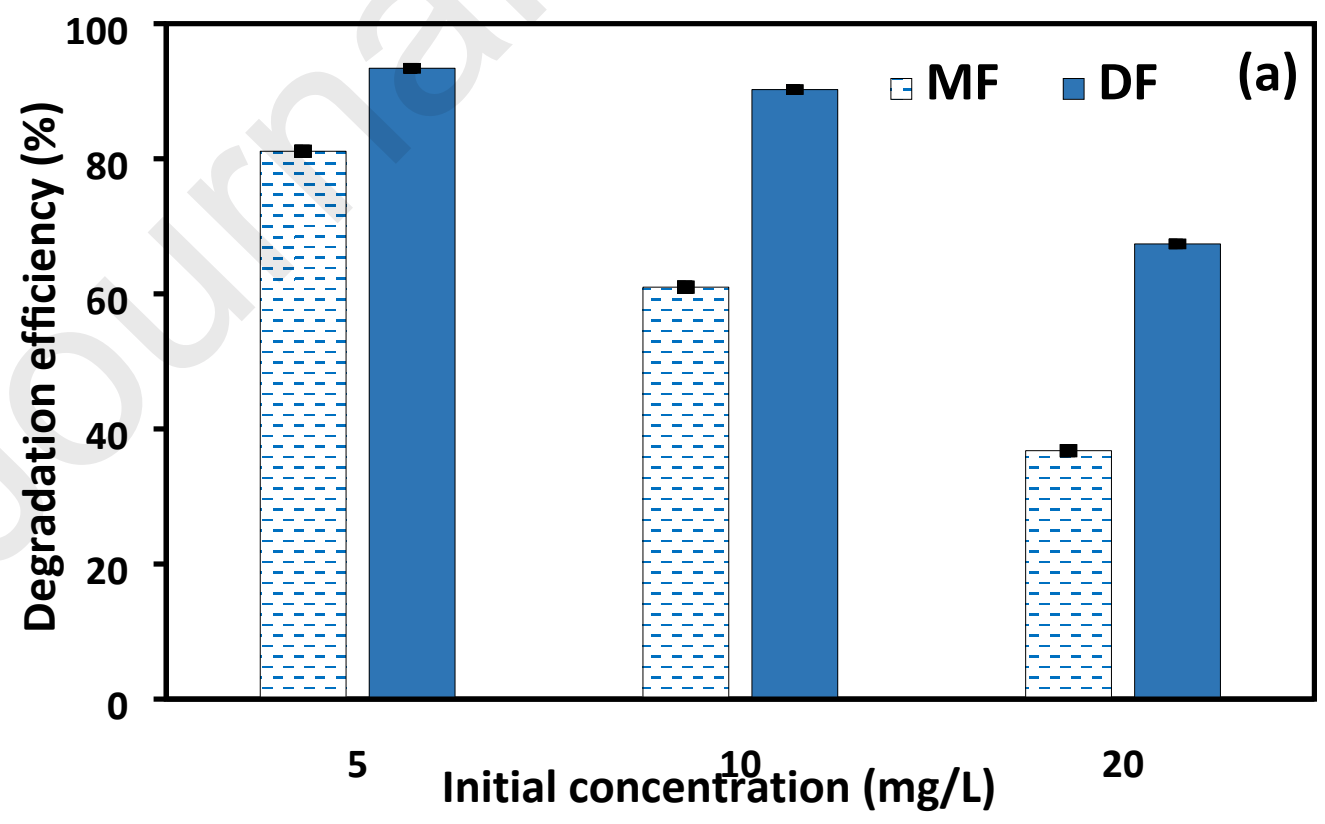




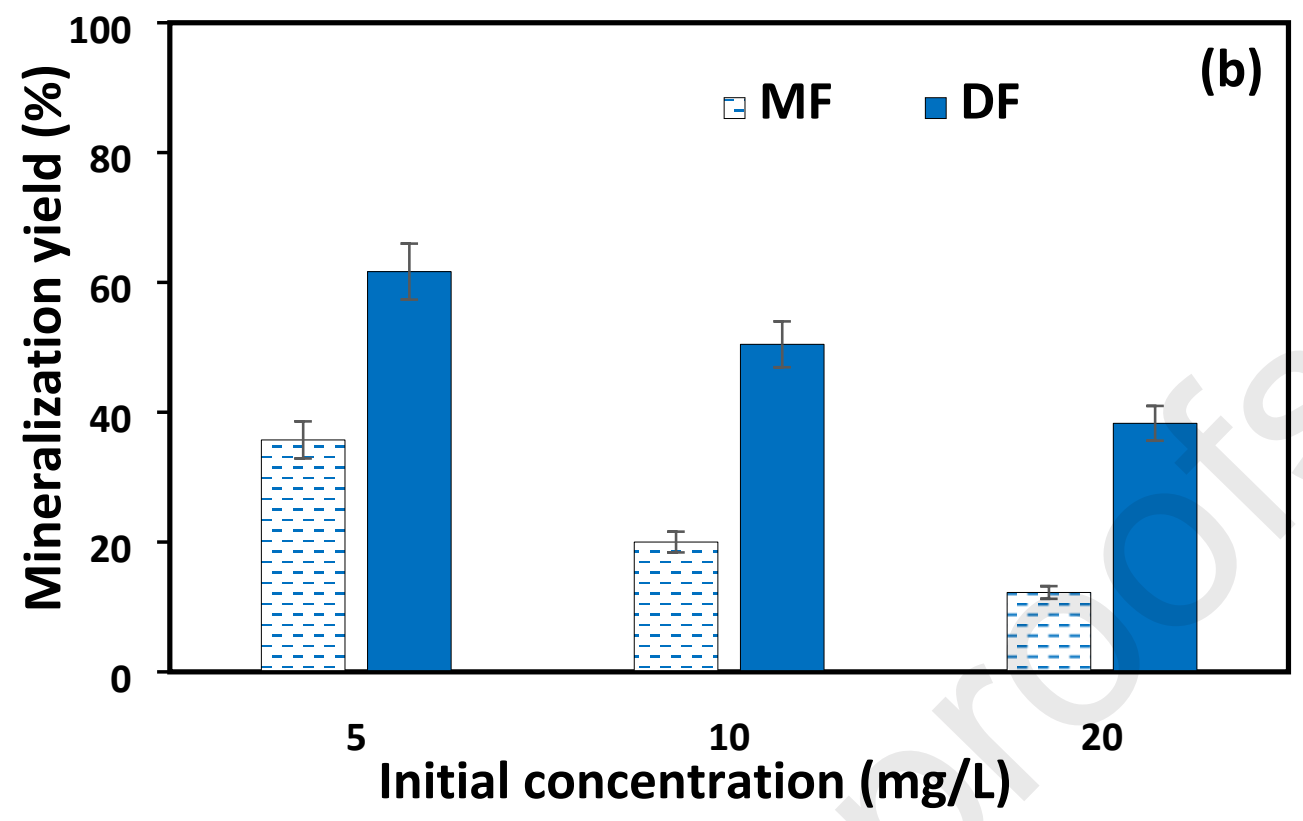

Figure 6. Comparison of the photocatalytic performances between the MF and DF. Degradation efficiency

(a) mineralization yield (b) versus initial concentration of $\mathrm{FLU}$ at $\mathrm{pH}=6.5 ;[\mathrm{FLU}]_{\mathrm{o}}=5-20 \mathrm{mg}^{\mathrm{L}-1}$; reaction volume $=600 \mathrm{~mL}$; reaction time $=330 \mathrm{~min}$

\subsection{Effect of the initial concentration of FLU}

The influence of the initial concentration was investigated for values in the range of 2.5$20 \mathrm{mg} \cdot \mathrm{L}^{-1}$ using the DF configuration; solution's $\mathrm{pH}$ was kept at 6.5. The degradation yields of the pollutant after 330 min irradiation are shown in Fig.7-a. Each experiment was made in duplicate.

Photolysis experiment (UVA/FLU) was carried out using only UV radiation with the luminous textile without $\mathrm{TiO}_{2}$ coating. After 330 min of UVA radiation, a low degradation yield was obtained (around $8 \%$ ). From one hand, it was proven that the FLU is prone to degradation under UV radiation due to the presence of quinolone structure $[48,49]$. On the other hand, other researchers have compered UV spectra and the absorption spectra 
of FLU in solution ( $20 \mathrm{mg} \cdot \mathrm{L}^{-1}$ ), an approximatively overlap from $300 \mathrm{~nm}$ to $360 \mathrm{~nm}$ was found between those two spectra showing that the FLU is absorbing in the UVA region of the electromagnetic spectra [50], this justifies the results obtained with FLU/UVA (figure 8-a) since the lamp emission of the luminous textile is centered at $365 \mathrm{~nm}$.

As shown in fig.7-a, the degradation efficiency decreased when the initial concentration increased; maximum degradation was achieved at $2.5 \mathrm{mg} \cdot \mathrm{L}^{-1} \mathrm{FLU}$, with a $96 \%$ using DF configuration. It is the consequence of a limited number of catalyst active sites, which limited the generation of oxidants, while the amount of pollutant increased. Similar phenomenon has also been reported by several researchers [51,52]. This observation can also be described by the linearized form of $\mathrm{L}-\mathrm{H}$ model that is frequently applied to rationalize the mechanism reactions taking place on the surface of solids [53]. This model is represented by Equation 7 .

$$
\frac{1}{r_{0}}=\frac{1}{k_{L-H} K_{L} C_{0}}+\frac{1}{k_{L-H}}
$$

Where $\frac{1}{r_{0}}$ is plotted versus $\frac{1}{C_{0}}$ (Fig. 7-b). The initial degradation rate, $r_{0}$, was calculated using $-\frac{d C}{d t}$ of each experiment at different initial FLU concentration (2.5-20 mg.L-1). Figure 7-b gives a linear relationship between $\frac{1}{r_{0}}$ and $\frac{1}{C_{0}}$ with an $\mathrm{R}^{2}$ value equal to 0.999 and the values of the constants $\mathrm{K}_{\mathrm{L}-\mathrm{H}}$ and $\mathrm{K}_{\mathrm{L}}$ were found to be respectively, 0.14 $\mathrm{mg} \cdot \mathrm{min}^{-1} \cdot \mathrm{L}^{-1}$ and $0.02 \mathrm{~L} \cdot \mathrm{mg}^{-1}$, namely in the same order of magnitude than those reported in previous studies for the pharmaceutical compounds degradation $[54,55]$. These results show that the Langmuir-Hinshelwood model is suitable to describe the FLU degradation kinetic under the experimental conditions studied in this work. 

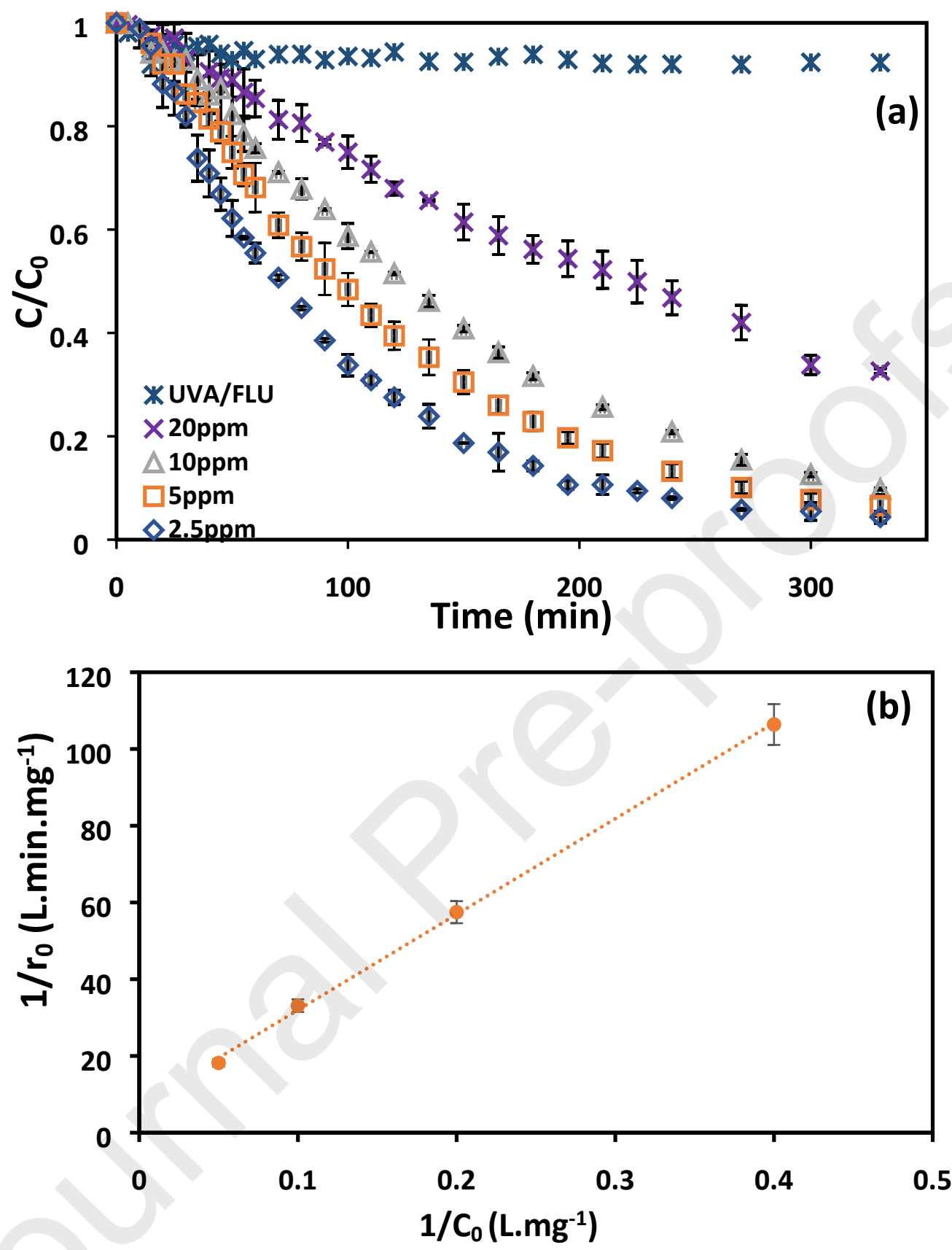

Figure 7. Time profiles of $\mathrm{C} / \mathrm{C}_{0}(\mathrm{a})$ and linearized Langmuir-Hinshelwood plot (b) for photocatalytic FLU degradation with $\mathrm{DF}$ configuration at $\mathrm{pH}=6.5 ;[\mathrm{FLU}]_{0}=2.5-20 \mathrm{mg} \cdot \mathrm{L}^{-1} ;$ reaction volume $=600 \mathrm{~mL}$; reaction time $=330 \mathrm{~min}$.

\subsection{Impact of oxidant addition}


The addition of an electron acceptor, such as $\mathrm{H}_{2} \mathrm{O}_{2}$ was shown to generate ${ }^{\circ} \mathrm{OH}$ radicals and reduce the electron hole recombination (eq. 8) [56]; hence it can improve the overall efficiency of the photocatalytic process. Therefore, the effect of different concentrations of $\mathrm{H}_{2} \mathrm{O}_{2}$ supply into the system (ranging from $1 \mathrm{mmol}^{-1}$ to $10 \mathrm{mmol} . \mathrm{L}^{-1}$ ) was examined considering the DF configuration at $[F L U]_{0}=20 \mathrm{mg} \cdot \mathrm{L}^{-1}$.

$$
\mathrm{e}^{-}+\mathrm{H}_{2} \mathrm{O}_{2} \rightarrow \cdot \mathrm{OH}+\mathrm{OH}^{-}
$$

Fig. 8 shows the effect of the addition of $\mathrm{H}_{2} \mathrm{O}_{2}$ on both the $\mathrm{k}_{\text {app }}$ and the mineralization yields after 100 min irradiation $\left(R^{2} \geq 0.985\right)$.

As seen in Fig.8-a, the $k_{a p p}$ constant was enhanced when the $\mathrm{H}_{2} \mathrm{O}_{2}$ concentration increased in the range of from 0 to $6 \mathrm{mmol} . \mathrm{L}^{-1}$, which may be explained by the formation of hydroxyl radicals. Nevertheless, when the $\mathrm{H}_{2} \mathrm{O}_{2}$ concentration reached a value beyond 6 mmol.L-1, the $k_{\text {app }}$ constant decreased; this might be due to the involvement of $\mathrm{H}_{2} \mathrm{O}_{2}$ as $\cdot \mathrm{OH}$ scavengers. Furthermore, the excess of these molecules involves increased rate of $\cdot \mathrm{OH}$ radicals recombination (Eq. 9) [57].

$$
\cdot \mathrm{OH}+{ }^{\circ} \mathrm{OH} \rightarrow \mathrm{H}_{2} \mathrm{O}_{2}
$$

The effect of $\mathrm{H}_{2} \mathrm{O}_{2}$ addition did not influence considerably the mineralization. Indeed, the yields did not vary significantly with the $\mathrm{H}_{2} \mathrm{O}_{2}$ amount most likely since part of the radicals produced are involved in the attack of the by-products formed, decreasing the amount of radicals available for FLU mineralization [58].

The highest mineralization yield (47\%) was obtained with 6 mmol.L-1 $\mathrm{H}_{2} \mathrm{O}_{2}$ (Fig.8-b). 

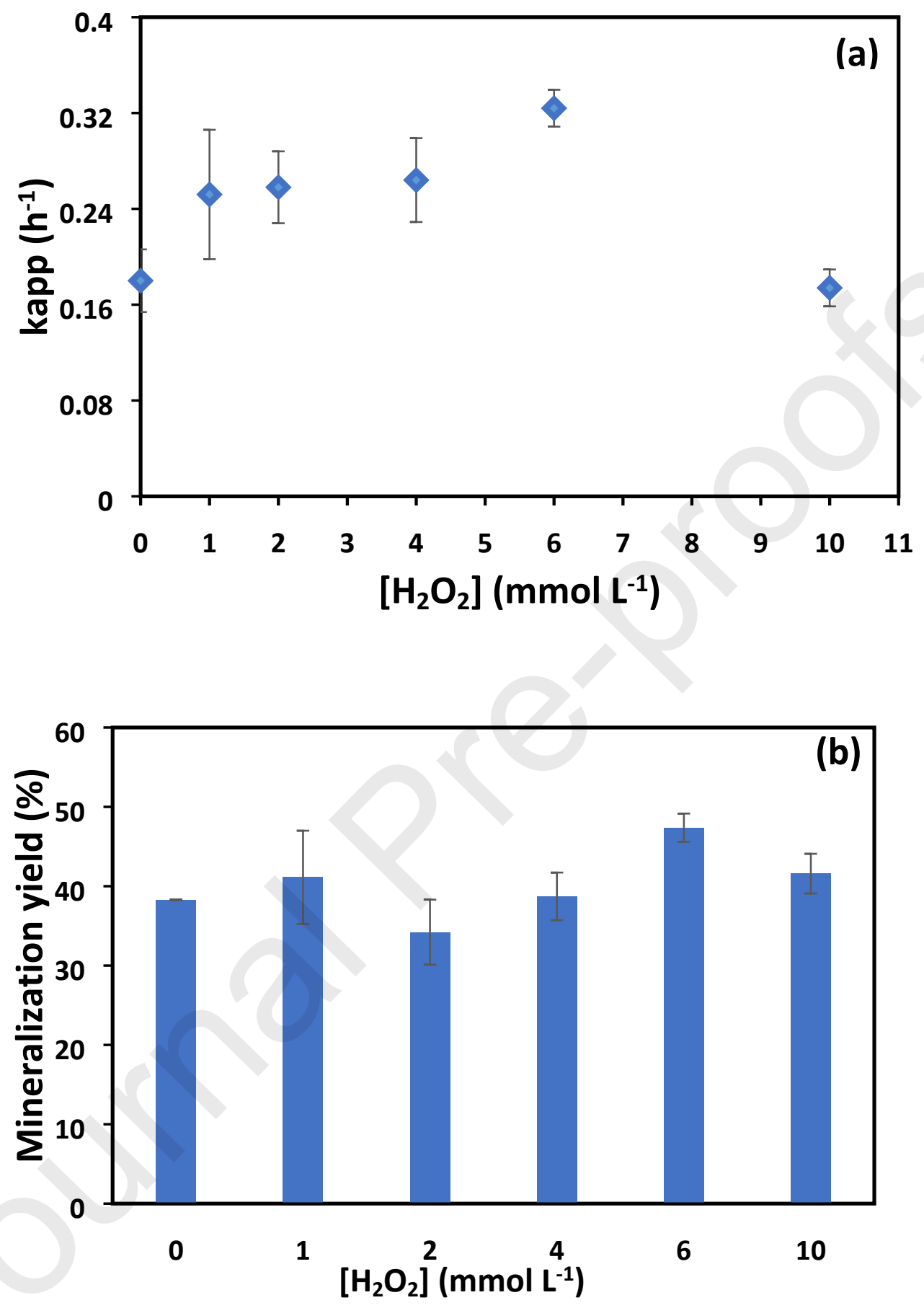

Figure 8. Effect of the $\mathrm{H}_{2} \mathrm{O}_{2}$ concentration on the FLU removal by the DF configuration at $\mathrm{pH} 6.5$ :

$[F L U]_{0}=20 \mathrm{mg} \cdot \mathrm{L}^{-1} ;$ reaction volume $=600 \mathrm{~mL}$; reaction time $=100 \mathrm{~min}$. Kinetic rate constants of FLU versus $\mathrm{H}_{2} \mathrm{O}_{2}$ concentration (a), mineralization yield versus $\mathrm{H}_{2} \mathrm{O}_{2}$ concentration after 330 min (b). 


\subsection{Effect of scavengers on photocatalytic FLU degradation}

Different compounds that alter the kinetic profile of organic pollutants oxidation have been implemented to establish the impact of the different species involved in the degradation [59]. In order to determine their contribution to the degradation of FLU, several types of scavengers were considered, and the respective rate constants calculated at $100 \mathrm{~min}$ of irradiation $\left(R^{2} \geq 0.986\right)$. As shown in Fig.9, non-obvious inhibitory effect was seen in the FLU kinetic when $\mathrm{CCl}_{4}$ was added into the pollutant solution $\left(k_{\text {app }}=0.174 \mathrm{~h}^{-1}\right)$, while a higher inhibition was observed after EDTA addition $\left(k_{\text {app }}=0.114 \mathrm{~h}^{-1}\right)$. Nevertheless, an extensive inhibition of antibiotic degradation was detected after the addition of tert-butanol with a constant rate of $0.084 \mathrm{~h}^{-1}$, suggesting that the ${ }^{\circ} \mathrm{OH}$ plays the major role in the mechanism of the photocatalytic FLU degradation. Similar results were reported by Rabahi et al, 2019 [60].

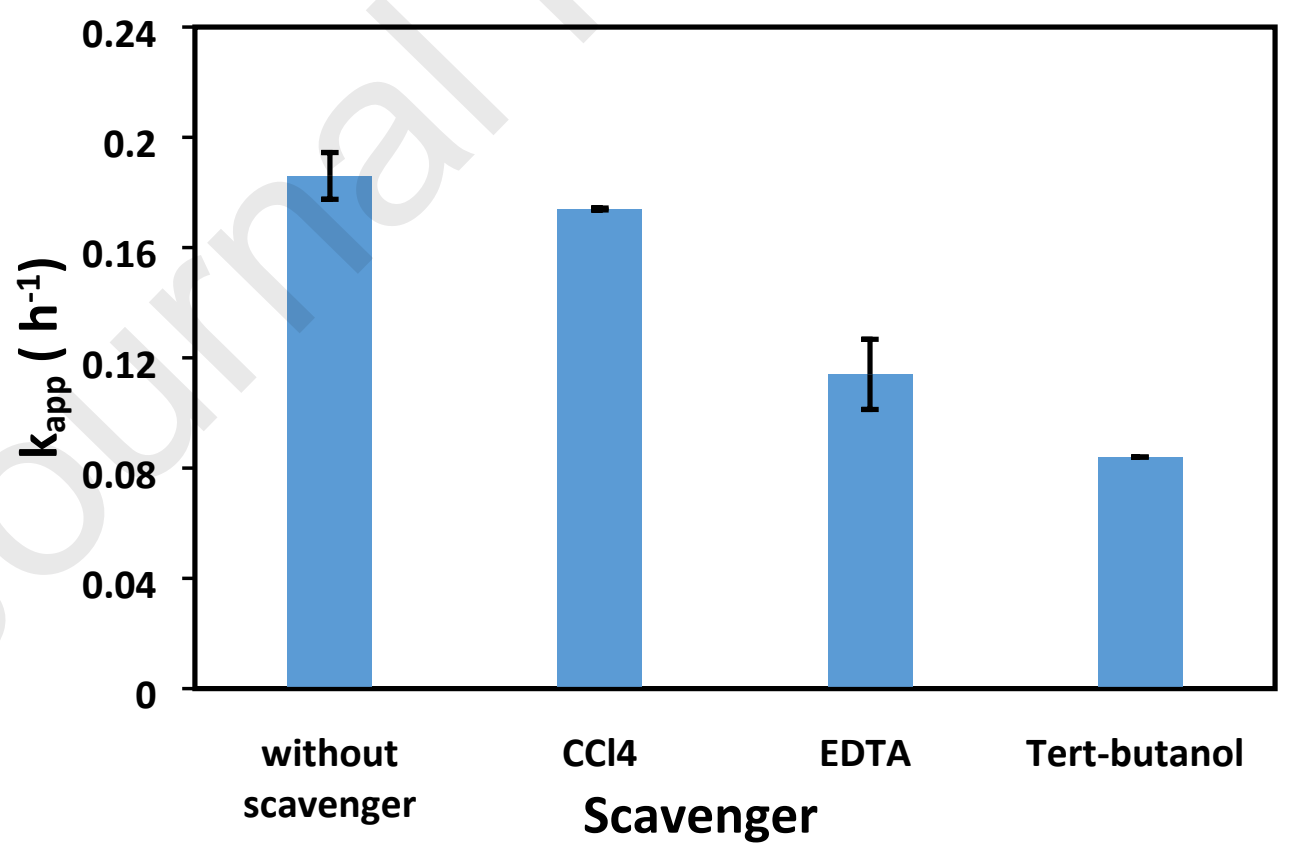


Figure 9. FLU kinetic rate constants versus scavengers for the DF configuration at : $\mathrm{pH} 6.5$, $[\mathrm{FLU}]_{0}=20 \mathrm{mg} \cdot \mathrm{L}^{-1} ;[$ Tert-butanol $]=50 \mathrm{mmol} \cdot \mathrm{L}-1 ;[$ EDTA $]=120 \mathrm{mg} \cdot \mathrm{L}-1 ; \mathrm{VCCl}_{4}=60 \mu \mathrm{L} ;$ reactional volume $=$ $600 \mathrm{~mL}$; reaction time $=100 \mathrm{~min}$.

\subsection{Comparative DF performance for elimination of FLU and CET}

In order to evaluate the luminous textile performance, the effect of the initial CET concentration (19.25- $\left.77.00 \mu \mathrm{mol} . \mathrm{L}^{-1}\right)$ was investigated. The degradation efficiency and the mineralization yield results were also compared with those obtained with FLU under the same conditions (Fig.10) (19.25-77 $\mu \mathrm{mol}^{\mathrm{L} \mathrm{L}^{-1}}$ is the equivalent of $5-20 \mathrm{mg} \cdot \mathrm{L}^{-1}$ of FLU). According to our review of the literature, FLU and CET are two molecules that are not found together in wastewater; the objective of this comparison was therefore to test the DF performances on a molecule which is more complex than the FLU, and belongs to another family (antihistamine). CET is commonly found in wastewater.

Degradation efficiency decreased from $68 \%$ to $44 \%$ and mineralization yield from $43 \%$ to $29 \%$ when CET concentration increased from 19.25 to $77.00 \mu \mathrm{mol} . \mathrm{L}^{-1}$ respectively. This might be due to the augmentation in the number of CET molecules with increasing concentration of pollutant, while the number of radical species remains constant, leading to a reduction in the photocatalytic performances [61]. Moreover, it was clearly seen in Fig.10-a and 10-b the higher photocatalytic performances regarding FLU compered to CET. Indeed, FLU degradation and mineralization were $93 \%$ and $62 \%$ respectively, whereas they were $68 \%$ and $43 \%$ for CET after 330 min of irradiation at $19.25 \mu$ mol.L-1. The difference in degradation and mineralization of pollutants is probably due to the fact that CET is more photo-stable than FLU $[62,63]$. 
On the other hand, time-dependent UV-vis spectra (Fig 10-c and 10-d) has been reported for FLU and CET photocatalytic degradation. The absorption peaks at $231 \mathrm{~nm}$ for CET and at $247 \mathrm{~nm}$ for FLU diminished gradually without displacement or modification of the spectrum at this wavelength for the two pollutants.
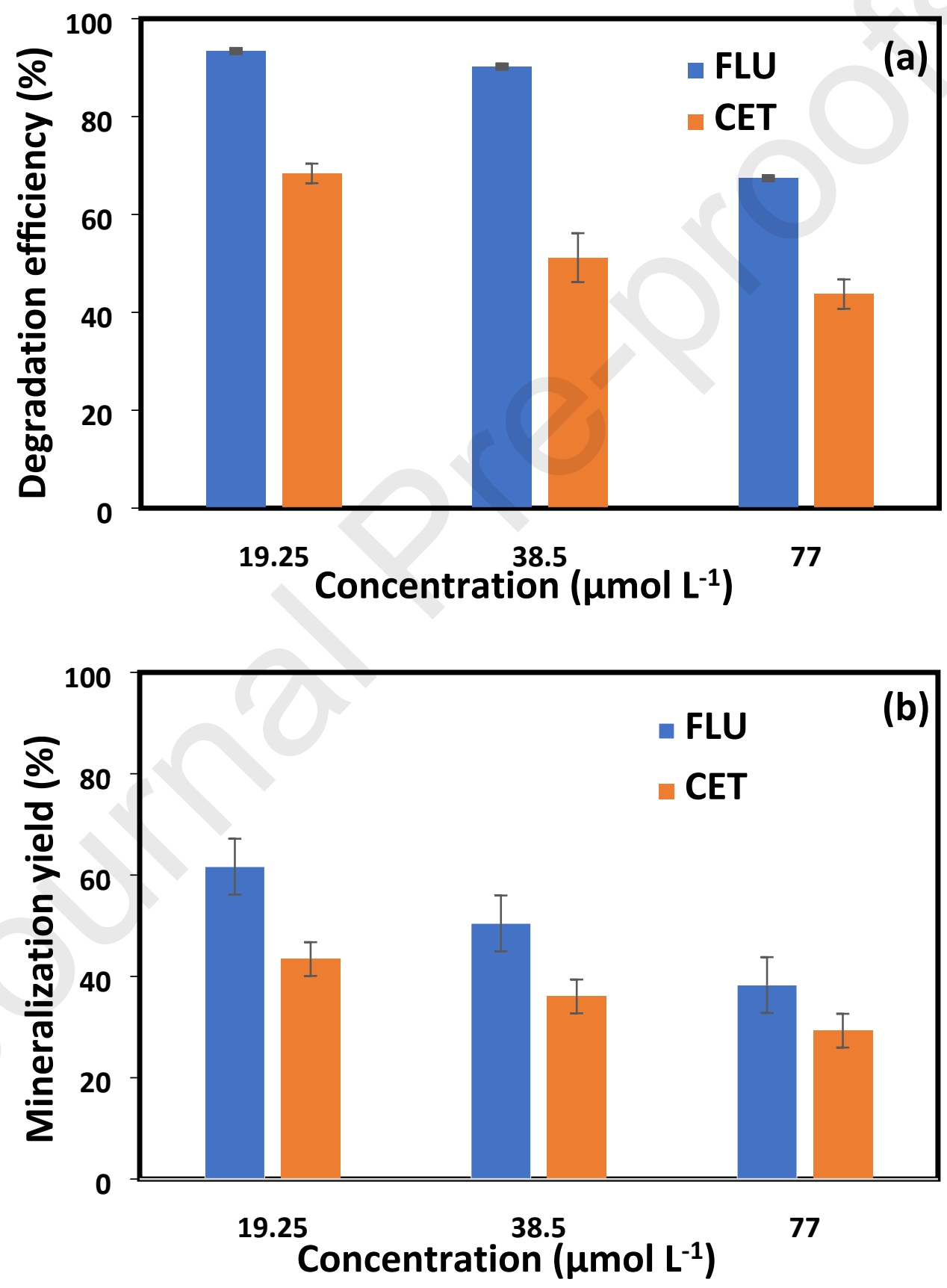

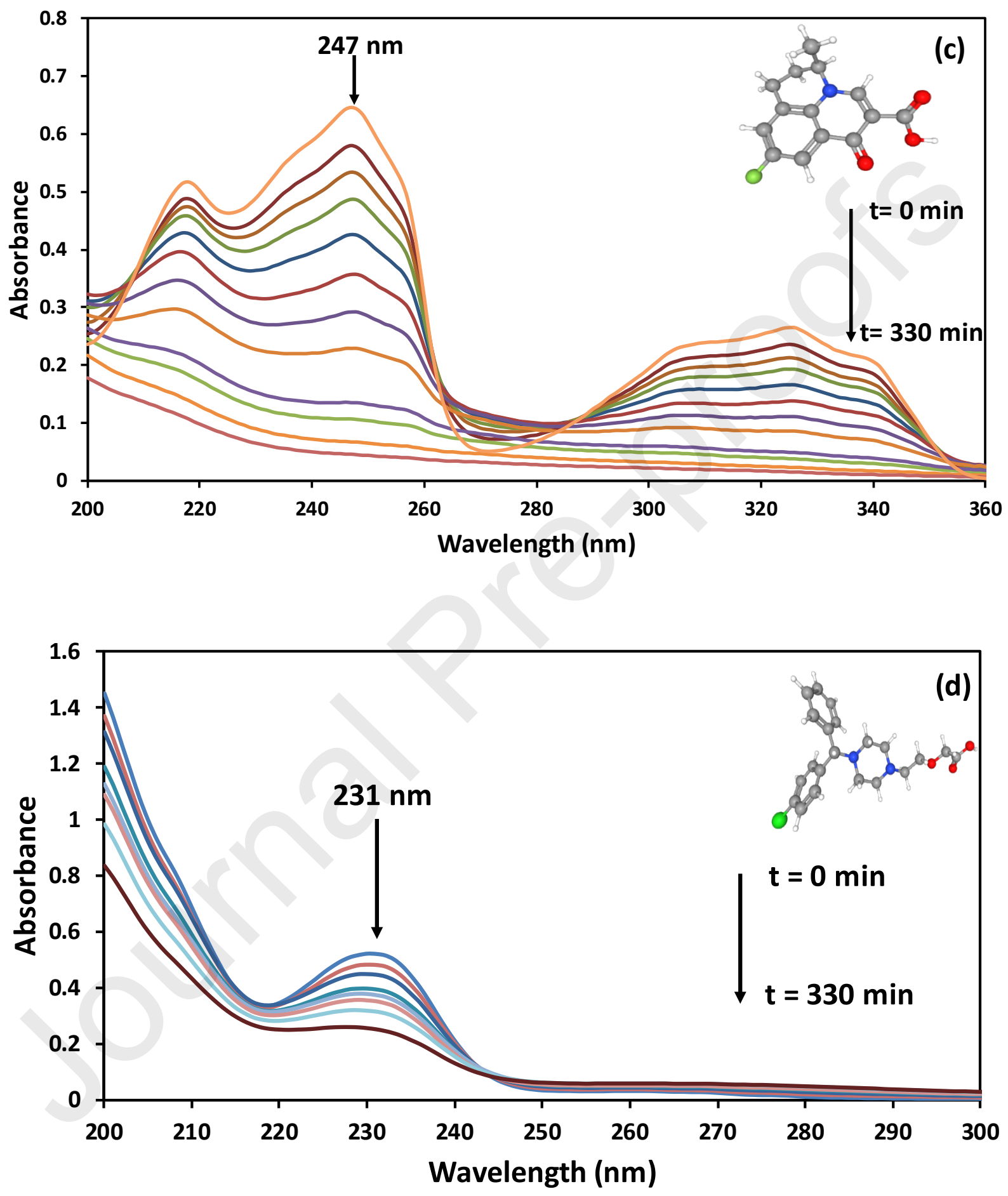

Figure 10. Comparison of the DF performances for the removal of FLU and CET. Textile DF configuration. Degradation efficiency (a) mineralization yield (b) versus initial concentration of FLU and CET at $\mathrm{pH}=6.5$; 
reaction volume $=600 \mathrm{~mL}$; reaction time $=330 \mathrm{~min}$. Time dependent UV-vis spectra of photocalalytic degradation of FLU (c) and CET (d) at $38.5 \mu \mathrm{mol} . \mathrm{L}^{-1}$.

As can be seen in the table 5, the DF shows very satisfying degradation rates, while using a lower light intensity compared to other studies applying $\mathrm{TiO}_{2}$ in suspension. The luminous textile has also the advantage of avoiding the post-treatment to separate the catalyst from the treated solution; it also allows the reduction of photoreactor size due to the integration of light source in the photocatalytic support.

Table 5. Comparison of the DF photocatalytic performance to the previous studies related to $\mathrm{TiO}_{2}$ photocatalysts.

\begin{tabular}{|c|c|c|c|c|c|c|c|c|c|}
\hline Photocatalyst & Pollutant & $\begin{array}{c}\text { [polluta } \\
\text { nt] } \\
\text { (mg.L-1) }\end{array}$ & $\begin{array}{c}\text { Dosage } \\
\left(g^{-1}\right)\end{array}$ & $\begin{array}{l}\text { Time } \\
\text { (min) }\end{array}$ & $\begin{array}{l}\text { Volume } \\
\text { (L) }\end{array}$ & $\begin{array}{c}\text { Degradation } \\
\text { (\%) }\end{array}$ & $\begin{array}{l}\text { Light } \\
\text { source }\end{array}$ & $\begin{array}{c}\text { light } \\
\text { intensity } \\
\text { (Watt) }\end{array}$ & Ref. \\
\hline Degussa P-25 & Sulfamethoxazole & 20 & 0,5 & 180 & 0.15 & 58 & UVA & 10 & [64] \\
\hline Degussa P-25 & Diclofenac & 20 & 1.25 & 180 & 0.15 & 50 & UVA & 10 & [64] \\
\hline $\mathrm{P}-25 \mathrm{TiO}_{2}$ & Doxazosin & 10 & 0.04 & 120 & 0.1 & 22 & UVA & 15 & [65] \\
\hline $\begin{array}{c}\text { DF Luminous } \\
\text { textile }\end{array}$ & Cetirizine & $\begin{array}{l}18(38.5 \\
\left.\mu m o l . L^{-1}\right)\end{array}$ & 0.6 & 180 & 0.6 & 34 & UVA & $4.91 \times 10^{-2}$ & $\begin{array}{l}\text { This } \\
\text { work }\end{array}$ \\
\hline
\end{tabular}




\begin{tabular}{|c|c|c|c|c|c|c|c|c|c|}
\hline Photocatalyst & Pollutant & $\begin{array}{c}\text { [polluta } \\
\text { nt] } \\
\left(\mathrm{mg} \cdot \mathrm{L}^{-1}\right)\end{array}$ & $\begin{array}{c}\text { Dosage } \\
\left(g^{-1}\right)\end{array}$ & $\begin{array}{l}\text { Time } \\
\text { (min) }\end{array}$ & $\begin{array}{c}\text { Volume } \\
\text { (L) }\end{array}$ & $\begin{array}{c}\text { Degradation } \\
\text { (\%) }\end{array}$ & $\begin{array}{l}\text { Light } \\
\text { source }\end{array}$ & $\begin{array}{c}\text { light } \\
\text { intensity } \\
\text { (Watt) }\end{array}$ & Ref. \\
\hline $\begin{array}{l}\text { DF Luminous } \\
\text { textile }\end{array}$ & Flumequine & $\begin{array}{l}10(38.5 \\
\left.\mu \mathrm{mol} . L^{-1}\right)\end{array}$ & 0.6 & 180 & 0.6 & 75 & UVA & $4.91 \times 10^{-2}$ & $\begin{array}{l}\text { This } \\
\text { work }\end{array}$ \\
\hline
\end{tabular}

\subsection{Effect of water matrices}

Tap water was the first water matrix studied during the photocatalytic process of the FLU, which main physico-chemical properties are summarized in Table.1-a.

The corresponding degradation efficiency of FLU and mineralization yields are shown in table 6 after 330 min irradiation.

Degradation efficiency and mineralization yield decreased with tap water compared to UPW, which may be explained by the composition of the matrix. Indeed, a number of studies have shown a negative impact of inorganic ions, such as nitrate and chlorides on $\mathrm{TiO}_{2}$ photocatalysis, leading to a decrease of the photodegradation efficiency $[66,67]$. However, the most significant inhibitory effect is related to the presence of nitrates anions (above $0.1 \mathrm{mmol} . \mathrm{L}^{-1}$, as in the present work), as it has been also documented in previous research [68], due to the larger anionic size of nitrate anions which blocks even more the active sites of catalyst [69]. The decline of photocatalytic activity may be also due to the role of nitrates anions as holes and radicals scavenging ( Eq. 10 and Eq. 11) [70].

$$
\begin{aligned}
& \mathrm{NO}_{3}{ }^{-}+\mathrm{h}^{+}=\mathrm{NO}_{3}{ }^{*} \\
& \mathrm{NO}_{3}{ }^{-}+{ }^{\cdot} \mathrm{OH}=\mathrm{NO}_{3}{ }^{*}+\mathrm{OH}^{-}
\end{aligned}
$$


Table 6. FLU degradation efficiency and mineralization yield versus matrices water with DF configuration at: $\mathrm{pH} 6.5,[\mathrm{FLU}]_{0}=20 \mathrm{mg} . \mathrm{L}^{-1}$; reaction time $=330 \mathrm{~min}$.

\section{Ultrapure water}

\begin{abstract}
Degradation (\%)
\end{abstract}
Mineralization (\%)
76

38
Tap water

61

26

$>$ Comparison between DF and CP for FLU degradation in both synthetic seawater (SW) and synthetic hospital wastewater (SHW)

One of the most important sources of pharmaceutical contaminants introduced into the marine environment is mainly related to the use of antibiotics in the activity of intensive marine aquaculture [71], in particular the administration of these substances to caged fish. Since FLU is a molecule commonly used in aquaculture, it has been detected in the marine environment [72]. Therefore, it seemed interesting to test the DF performance for the treatment of a synthetic solution simulating seawater (SW) containing FLU contaminant; this solution was prepared by adding $33 \mathrm{~g} \mathrm{~L}^{-1}$ of $\mathrm{NaCl}$ to achieve the salinity of seawater [73].

In order to get closer to the real conditions, experiments were also performed by using SHW similar to an effluent from the University Hospital Center of Rennes (Rennes City, France); this experience was a first step before the treatment of a real wastewater. Indeed, we were unable to obtain this effluent due to the high risk of the presence of Covid-19 in it. SHW was prepared by adding different elements to tap water containing FLU (100 $\mathrm{mg} \cdot \mathrm{L}^{-1}$ of sucrose, $50 \mathrm{mg} \cdot \mathrm{L}^{-1}$ of citric acid, $400 \mathrm{mg} \cdot \mathrm{L}^{-1}$ of $\mathrm{NaCl}$ and $\left.230 \mathrm{mg} \cdot \mathrm{L}^{-1} \mathrm{Na}_{2} \mathrm{HPO}_{4}\right)$. 
To compare the DF efficiency with the conventional process under similar conditions as encountered in real effluents, we performed experiments on the DF and CP in different water matrices (UPW, SW and SHW). The comparison between these two processes was made in terms of FLU apparent quantum yield (Eq. 5) at 10 mg.L-1 (with $R^{2} \geq 0.997$ for the initial slope).

As can be seen in Fig.11, the DF was significantly more efficient over CP in all water matrices studied, which confirmed the effectiveness of this technology. Fig. 11 also shows that for both catalysts (DF and CP) a lower value of the apparent quantum yield in the simulated matrices (SW and SHW) were observed if compared to the apparent quantum yields in UPW. Regarding the simulated seawater, SW, this could be explained by the low solubility of oxygen due to the ionic strength of the reaction volume, and it also can be due to the presence of chloride ions at a high concentration which act as scavengers of the hole and the radical species responsible for the FLU degradation [74]. The mechanism of scavenging by chloride ions was proposed by Matthews and McEnvoy (Eq. 12 and Eq. 13) $[75]$.

$$
\begin{aligned}
& \mathrm{Cl}^{-}+\cdot \mathrm{OH}=\cdot \mathrm{Cl}+\mathrm{OH}^{-} \\
& \mathrm{Cl}^{-}+\mathrm{h}^{+}=\cdot \mathrm{Cl}
\end{aligned}
$$

However, the decrease was significantly more pronounced in SHW if compared to SW. This decline may be due to the presence of inorganic ions (Table 1.b) in the SHW. In fact, a number of studies have reported that the presence of salts causes photocatalytic deactivation of $\mathrm{TiO}_{2}$ because they can be adsorbed on the surface of the catalyst, reducing the contact between the pollutant and the $\mathrm{TiO}_{2}$ [76], their presence can also cause a 
decrease in colloidal stability. Adding to this, inorganic ions such as those present in SHW namely nitrates (Eq. 10 and Eq. 11), chlorides (Eq. 12 and Eq.13), phosphates (Eq. 14) and sulfates (Eq. 15 and Eq. 16) can be scavengers of holes and hydroxyl groups $[77,78]$.

$$
\begin{aligned}
& \cdot \mathrm{OH}+\mathrm{HPO}_{4}{ }^{2-} \rightarrow \mathrm{HPO}_{4}{ }^{-}+\mathrm{OH}^{-} \\
& \cdot \mathrm{OH}+\mathrm{SO}_{4}{ }^{2-} \rightarrow \cdot \mathrm{SO}_{4}{ }^{2-} \\
& \mathrm{h}^{+}+\mathrm{SO}_{4}{ }^{2-} \rightarrow \cdot \mathrm{SO}_{4}{ }^{2-}
\end{aligned}
$$

Indeed in Fig.11, an almost total inhibition can be seen in the case of CP with a drop of $88 \%$ in the apparent quantum yield if compared to UPW; while in the case of the DF it was only $36 \%$. Moreover, in a previous study, a total inhibition of the FLU degradation rate was noticed in a SHW with the same characteristics, by using nano-sized iron oxides (FeOx) supported on polyester textile as catalyst [32]. 


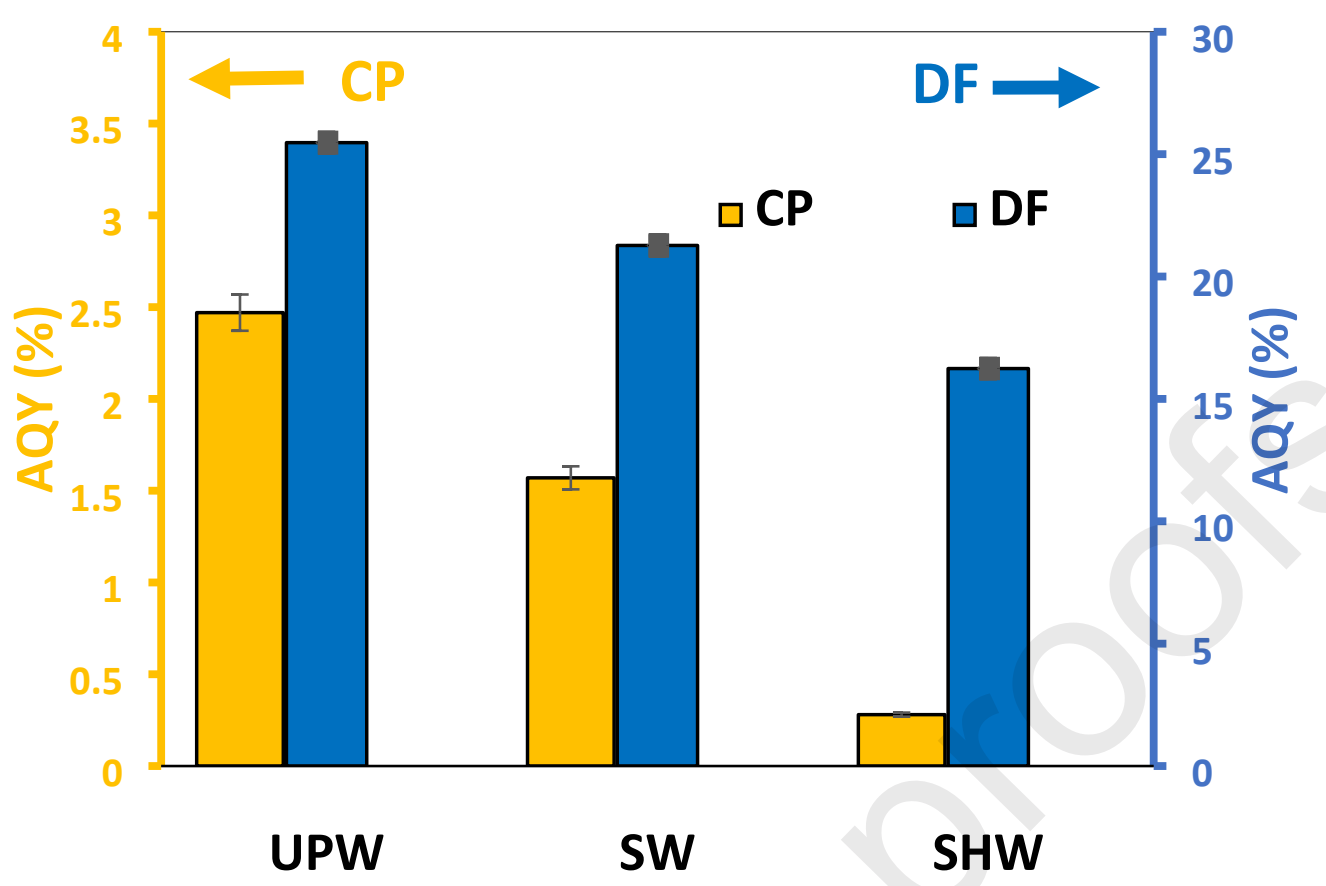

Figure 11. Comparison of the photocatalytic performances between the DF and the CP in different matrices; $[F L U]_{0}=10 \mathrm{mg} \mathrm{L}^{-1} ; \Phi(\mathrm{DF})=8.810^{-2} \mathrm{~W} ; \Phi(\mathrm{CP})=30 \mathrm{~W}$; reaction volume $=600 \mathrm{~mL} ; \mathrm{pH} 6.5$.

\subsection{Reusability of the luminous textile}

To investigate the photocatalytic stability and reusability of the luminous textile, various experiments were performed for FLU by reusing the luminous textile over several cycles. For each new cycle, DF configuration was regenerated under UVA and stirring in UPW for about 90 min. Four cycles of reuse were carried out, considering for each cycle a fresh solution of FLU at $2.5 \mathrm{mg.L}-1$. It should be noticed that between each cycle, several experiments were performed, namely 6 between the first and the second cycle, 13 between the second and the third, and 18 between the third and the fourth cycle. Each of these experiments were run for 330 min followed by the operation of regeneration for 90 min. It is worth noting that between the first and the last cycle, 41 experiments and regenerations were performed corresponding to a total of about 12 days of photocatalysis. 
As seen in Fig.12, degradation efficiency remained nearly unchanged throughout these numerous experiments, which demonstrates that this technology is robust; the photocatalyst can be recovered and reused without significant loss of activity.

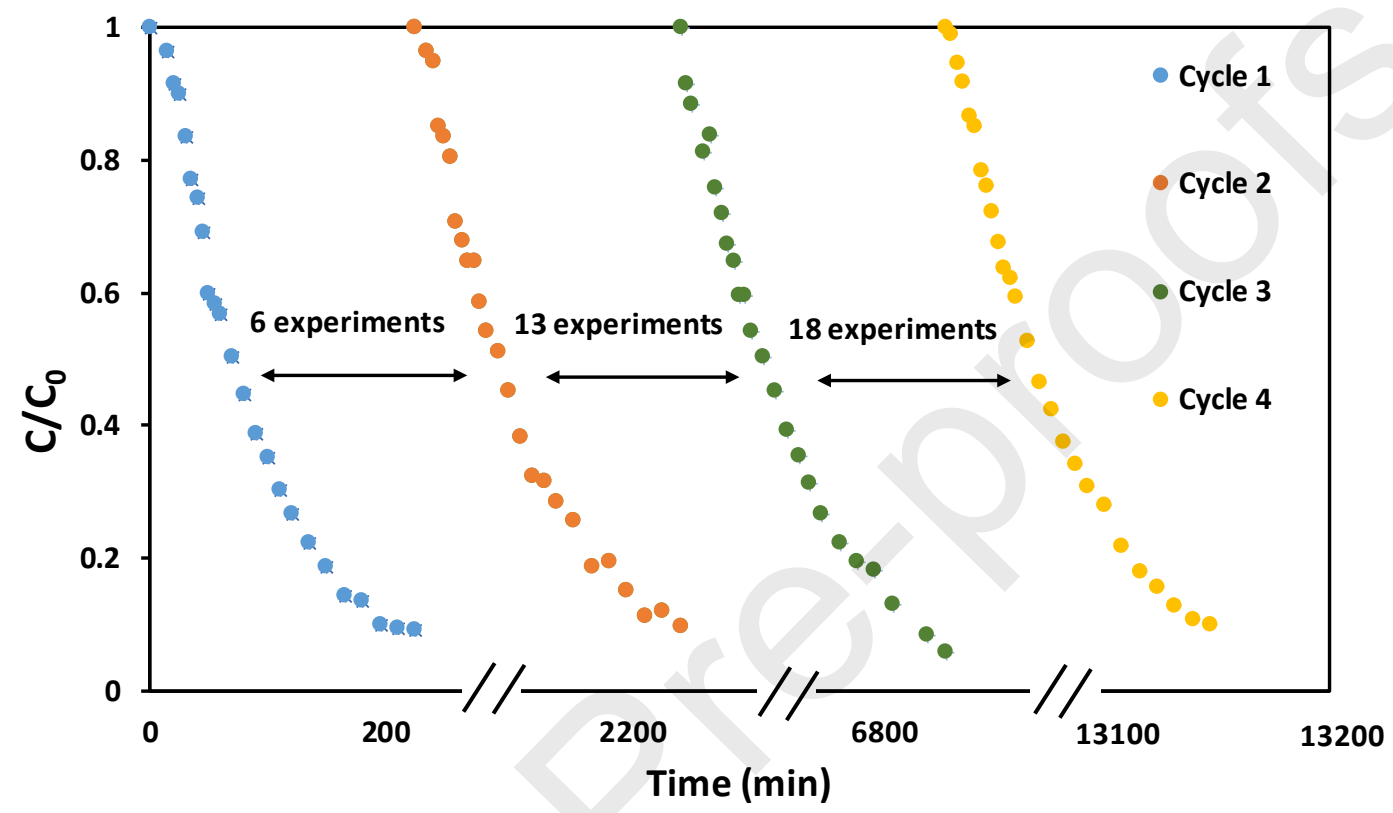

Figure 12. Reusability cycles of DF luminous textile at $\mathrm{pH} 6.5,[\mathrm{FLU}]_{0}=2.5 \mathrm{mg} \cdot \mathrm{L}^{-1}$; reaction time $=225 \mathrm{~min}$.

\subsection{Pilot scale application}

This study also aims at verifying the possibility of adapting the luminous textile to industrial conditions by developing a second experimental device using an annular recirculating reactor (Fig.4-c and 4-d). The effect of the initial FLU concentration was studied at the pilot-scale and compared with the results obtained at the laboratory-scale in terms of FLU apparent quantum yield.

As can be seen in the Fig.13, the apparent quantum yield obtained on the pilot was higher than the one obtained on the lab-scale $\left(R^{2} \geq 0.998\right)$. This can be explained by a higher 
flow rate in the case of the pilot-scale allowing the reduction of limitations due to mass transfer [46].

On the other hand, these results also indicate that the light textile maintained its performance; while for almost the same light intensity as the one used on the small scale, its surface area was increased (almost three times), as well as the volume of treated water (2 L) (by more than three times). Indeed, the light intensities of the DF at the lab-scale and the pilot-scale were 2.9 and $3.3 \mathrm{~W} . \mathrm{m}^{-2}$, respectively.

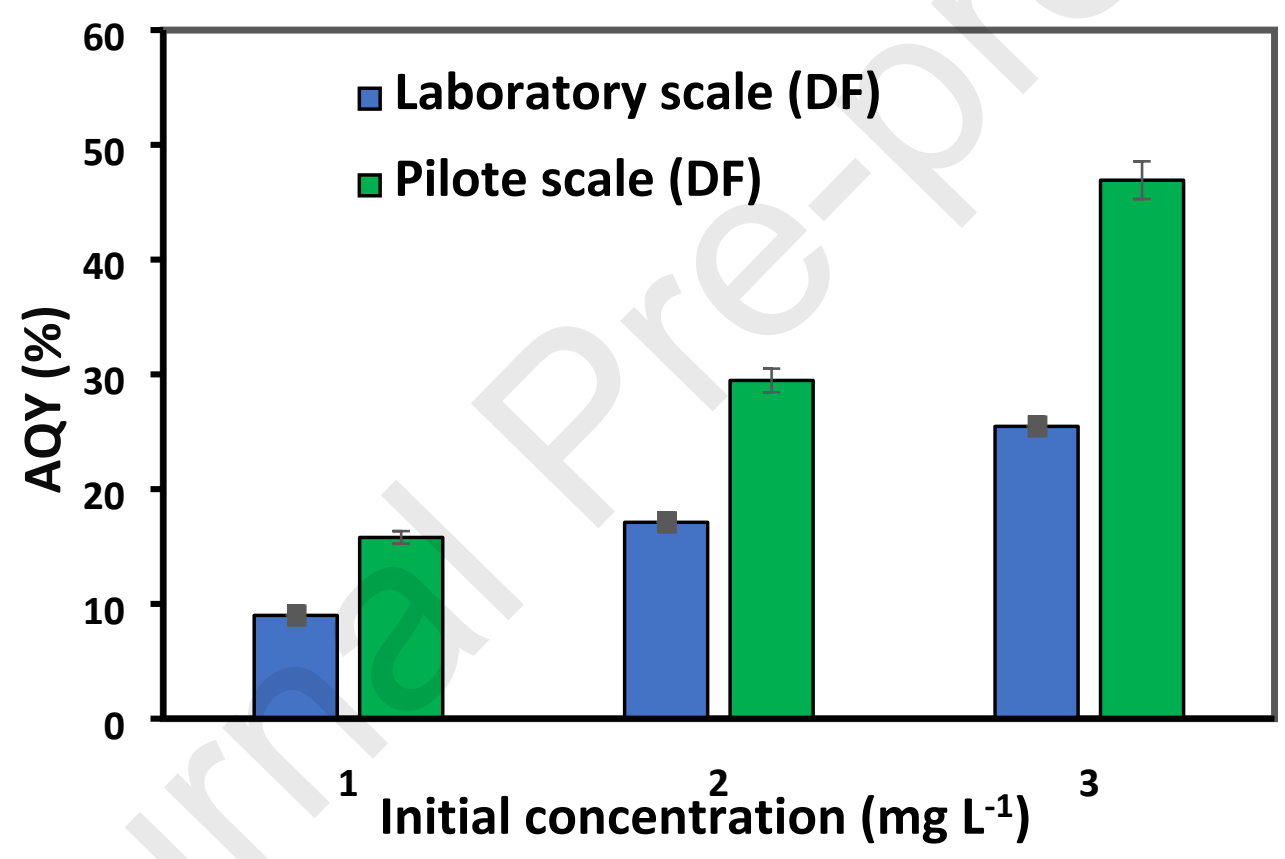

Figure 13. Comparison of the photocatalytic performances between the DF at laboratory-scale and pilotscale. $[\mathrm{FLU}]_{0}=2.5-10 \mathrm{mg} \cdot \mathrm{L}^{-1} ; \Phi(\mathrm{DF}$ at lab-scale $)=2.9 \mathrm{~W} \cdot \mathrm{m}^{-2} ; \Phi($ DF at pilot-scale $)=3.3 \mathrm{~W} \cdot \mathrm{m}^{-2}$; reaction volume $=2000 \mathrm{~mL} ;$ reaction time $=20 \mathrm{~min} ; \mathrm{pH} 6.5$.

\section{Conclusion}

An innovative luminous textile was considered in the present study for the intensification of the heterogeneous $\mathrm{TiO}_{2}$ photocatalysis under UVA-LED irradiation. Two different types 
of pharmaceutical compounds, flumequine (antibiotic) and cetirizine (antihistaminic), were used in aqueous solution to evaluate the photocatalytic performances of the luminous textile. After confirming that this technology was more efficient than the conventional process, various parameters were examined on the textile showing a high degradation of FLU at $2.5 \mathrm{mg}^{-1}{ }^{-1}$ initial concentration (96\%) with the double-face configuration. The photocatalytic performances of this last configuration was better than that obtained with the mono-face one in terms of FLU degradation and mineralization, with $93 \%$ and $62 \%$ for $5 \mathrm{mg} \cdot \mathrm{L}^{-1}$ after 330min irradiation, respectively. These results were also compared with those obtained for the elimination of CET, showing a lower efficiency for CET removal. The presence of $\mathrm{H}_{2} \mathrm{O}_{2}$ improves the apparent kinetic constant $\left(k_{\text {app }}\right)$ of $\mathrm{FLU}$, and the optimal $\mathrm{H}_{2} \mathrm{O}_{2}$ dosage was equal to 6 mmol.L-1. The photocatalytic activity of the luminous textile did not decrease even after repeated uses, retaining its catalytic performance after at least about $287 \mathrm{~h}$ of operation. Moreover, the textile showed better efficiency than the cellulosic paper in the various water matrices studied and also maintained its performance at the pilot-scale.

Overall, the outcome of the present work suggests that the luminous textile is an excellent photocatalyst for the photocatalytic degradation process, improving the contact between the light, the catalyst and the pollutant, as well as reducing the energy consumption by using LED.

\section{Acknowledgments}

The authors are grateful to Sebastien Potel (UniLaSalle-Beauvais) for SEM-EDX characterization, to Campus France through PROFAS B+ program for its financial support 
in this collaborative project and to Brochier Technologies for providing the optical fiber fabrics. 


\section{References}

[1] G. Ghasemzadeh, M. Momenpour, F. Omidi, M.R. Hosseini, M. Ahani, A. Barzegari, Applications of nanomaterials in water treatment and environmental remediation, Frontiers of Environmental Science \& Engineering. 8 (2014) 471-482. https://doi.org/10.1007/s11783-014-0654-0.

[2] L. Liu, Z. Liu, H. Bai, D.D. Sun, Concurrent filtration and solar photocatalytic disinfection/degradation using high-performance Ag/TiO2 nanofiber membrane, Water Research. 46 (2012) 1101-1112. https://doi.org/10.1016/j.watres.2011.12.009.

[3] M. Bilal, M. Adeel, T. Rasheed, Y. Zhao, H.M.N. Iqbal, Emerging contaminants of high concern and their enzyme-assisted biodegradation - A review, Environment International. 124 (2019) 336-353. https://doi.org/10.1016/j.envint.2019.01.011.

[4] T. Singh, N. Srivastava, P.K. Mishra, A.K. Bhatiya, N.L. Singh, Application of $\mathrm{TiO}_{2}$ Nanoparticle in Photocatalytic Degradation of Organic Pollutants, MSF. $855 \quad$ (2016) 20-32. https://doi.org/10.4028/www.scientific.net/MSF.855.20.

[5] F. Yu, Y. Li, S. Han, J. Ma, Adsorptive removal of antibiotics from aqueous solution using carbon materials, Chemosphere.

153 365-385. https://doi.org/10.1016/j.chemosphere.2016.03.083.

[6] K. Zare, V.K. Gupta, O. Moradi, A.S.H. Makhlouf, M. Sillanpää, M.N. Nadagouda, H. Sadegh, R. Shahryari-ghoshekandi, A. Pal, Z. Wang, I. Tyagi, M. Kazemi, A comparative study on the basis of adsorption capacity between CNTs and activated carbon as adsorbents for removal of noxious synthetic dyes: a review, J Nanostruct Chem. 5 (2015) 227-236. https://doi.org/10.1007/s40097015-0158-x.

[7] I. Béchohra, A. Couvert, A. Amrane, Absorption and biodegradation of toluene: Optimization of its initial concentration and the biodegradable non-aqueous phase liquid volume fraction, International 
$\begin{array}{lllll}\text { Biodeterioration } & \& \quad & \text { Biodegradation. } & 104 & \text { (2015) }\end{array}$ https://doi.org/10.1016/j.ibiod.2015.07.004.

[8] M. de Kwaadsteniet, P.H. Dobrowsky, A. van Deventer, W. Khan, T.E. Cloete, Domestic Rainwater Harvesting: Microbial and Chemical Water Quality and Point-of-Use Treatment Systems, Water Air Soil Pollut. 224 (2013) 1629. https://doi.org/10.1007/s11270-013-1629-7.

[9] R. Liang, J.C. Van Leuwen, L.M. Bragg, M.J. Arlos, L.C.M. Li Chun Fong, O.M. Schneider, I. JaciwZurakowsky, A. Fattahi, S. Rathod, P. Peng, M.R. Servos, Y.N. Zhou, Utilizing UV-LED pulse width modulation on $\mathrm{TiO} 2$ advanced oxidation processes to enhance the decomposition efficiency of pharmaceutical micropollutants, Chemical Engineering Journal. 361 (2019) 439-449. https://doi.org/10.1016/j.cej.2018.12.065.

[10] M. Nasr, C. Eid, R. Habchi, P. Miele, M. Bechelany, Recent Progress on Titanium Dioxide Nanomaterials for Photocatalytic Applications, ChemSusChem. 11 (2018) 3023-3047. https://doi.org/10.1002/cssc.201800874.

[11] A. Carabin, P. Drogui, D. Robert, Photo-degradation of carbamazepine using TiO2 suspended photocatalysts, Journal of the Taiwan Institute of Chemical Engineers. 54 (2015) 109-117. https://doi.org/10.1016/j.jtice.2015.03.006.

[12] A. Patchaiyappan, S. Saran, S.P. Devipriya, Recovery and reuse of TiO2 photocatalyst from aqueous suspension using plant based coagulant - A green approach, Korean J. Chem. Eng. 33 (2016) 21072113. https://doi.org/10.1007/s11814-016-0059-9.

[13] W.M. Samhaber, M.T. Nguyen, Applicability and costs of nanofiltration in combination with photocatalysis for the treatment of dye house effluents, Beilstein Journal of Nanotechnology. 5 (2014) 476-484. https://doi.org/10.3762/bjnano.5.55. 
[14] P. Westerhoff, P. Alvarez, Q. Li, J. Gardea-Torresdey, J. Zimmerman, Overcoming implementation barriers for nanotechnology in drinking water treatment, Environ. Sci.: Nano. 3 (2016) 1241-1253. https://doi.org/10.1039/C6EN00183A.

[15] R. van Grieken, J. Marugán, C. Sordo, P. Martínez, C. Pablos, Photocatalytic inactivation of bacteria in water using suspended and immobilized silver-TiO2, Applied Catalysis B: Environmental. 93 (2009) 112-118. https://doi.org/10.1016/j.apcatb.2009.09.019.

[16] R. Zhou, M.I. Guzman, CO2 Reduction under Periodic Illumination of ZnS, J. Phys. Chem. C. 118 (2014) 11649-11656. https://doi.org/10.1021/jp4126039.

[17] R. Zhou, M.I. Guzman, Photocatalytic Reduction of Fumarate to Succinate on ZnS Mineral Surfaces, J. Phys. Chem. C. 120 (2016) 7349-7357. https://doi.org/10.1021/acs.jpcc.5b12380.

[18] R.E. Marinangeli, D.F. Ollis, Photoassisted heterogeneous catalysis with optical fibers: I. Isolated single fiber, AIChE Journal. 23 (1977) 415-426. https://doi.org/10.1002/aic.690230403.

[19] A. Danion, J. Disdier, C. Guillard, N. Jaffrezic-Renault, Malic acid photocatalytic degradation using a TiO2-coated optical fiber reactor, Journal of Photochemistry and Photobiology A: Chemistry. 190 (2007) 135-140. https://doi.org/10.1016/j.jphotochem.2007.03.022.

[20] A. Danion, J. Disdier, C. Guillard, O. Païssé, N. Jaffrezic-Renault, Photocatalytic degradation of imidazolinone fungicide in TiO2-coated optical fiber reactor, Applied Catalysis B: Environmental. 62 (2006) 274-281. https://doi.org/10.1016/j.apcatb.2005.08.008.

[21] A. Danion, J. Disdier, C. Guillard, F. Abdelmalek, N. Jaffrezic-Renault, Characterization and study of a single-TiO2-coated optical fiber reactor, Applied Catalysis B: Environmental. 52 (2004) 213-223. https://doi.org/10.1016/j.apcatb.2004.04.005.

[22] P.-A. Bourgeois, E. Puzenat, L. Peruchon, F. Simonet, D. Chevalier, E. Deflin, C. Brochier, C. Guillard, Characterization of a new photocatalytic textile for formaldehyde removal from indoor air, Applied Catalysis B: Environmental. 128 (2012) 171-178. https://doi.org/10.1016/j.apcatb.2012.03.033. 
[23] C. Indermühle, E. Puzenat, F. Simonet, L. Peruchon, C. Brochier, C. Guillard, Modelling of UV optical ageing of optical fibre fabric coated with TiO2, Applied Catalysis B: Environmental. 182 (2016) 229235. https://doi.org/10.1016/j.apcatb.2015.09.037.

[24] M. Feng, L. Yan, X. Zhang, P. Sun, S. Yang, L. Wang, Z. Wang, Fast removal of the antibiotic flumequine from aqueous solution by ozonation: Influencing factors, reaction pathways, and toxicity evaluation, $\begin{array}{llllll}\text { Science of The } & \text { Total }\end{array}$ https://doi.org/10.1016/j.scitotenv.2015.09.048.

[25] M. Feng, R. Qu, X. Zhang, P. Sun, Y. Sui, L. Wang, Z. Wang, Degradation of flumequine in aqueous solution by persulfate activated with common methods and polyhydroquinone-coated magnetite/multi-walled carbon nanotubes catalysts, Water Research. 85 (2015) 1-10. https://doi.org/10.1016/j.watres.2015.08.011.

[26] J. Iqbal, N.S. Shah, M. Sayed, N. Muhammad, S.- Rehman, J.A. Khan, Z.U. Haq Khan, F.M. Howari, Y. Nazzal, C. Xavier, S. Arshad, A. Hussein, K. Polychronopoulou, Deep eutectic solvent-mediated synthesis of ceria nanoparticles with the enhanced yield for photocatalytic degradation of flumequine under UV-C, Journal of Water Process Engineering. 33 (2020) 101012. https://doi.org/10.1016/j.jwpe.2019.101012.

[27] A. Labella, M. Gennari, V. Ghidini, I. Trento, A. Manfrin, J.J. Borrego, M.M. Lleo, High incidence of antibiotic multi-resistant bacteria in coastal areas dedicated to fish farming, Mar. Pollut. Bull. 70 (2013) 197-203. https://doi.org/10.1016/j.marpolbul.2013.02.037.

[28] J. Kosonen, L. Kronberg, The occurrence of antihistamines in sewage waters and in recipient rivers, Environ Sci Pollut Res. 16 (2009) 555-564. https://doi.org/10.1007/s11356-009-0144-2.

[29] A. Bahlmann, J.J. Carvalho, M.G. Weller, U. Panne, R.J. Schneider, Immunoassays as high-throughput tools: Monitoring spatial and temporal variations of carbamazepine, caffeine and cetirizine in surface 
and

wastewaters,

Chemosphere.

89

(2012)

$1278-1286$.

https://doi.org/10.1016/j.chemosphere.2012.05.020.

[30] J. Fick, H. Söderström, R.H. Lindberg, C. Phan, M. Tysklind, D.G.J. Larsson, Contamination of surface, ground, and drinking water from pharmaceutical production, Environmental Toxicology and Chemistry. 28 (2009) 2522-2527. https://doi.org/10.1897/09-073.1.

[31] M. Teixeira, Â. Almeida, V. Calisto, V.I. Esteves, R.J. Schneider, F.J. Wrona, A.M.V.M. Soares, E. Figueira, R. Freitas, Toxic effects of the antihistamine cetirizine in mussel Mytilus galloprovincialis, Water Research. 114 (2017) 316-326. https://doi.org/10.1016/j.watres.2017.02.032.

[32] G.N. Coulibaly, S. Bae, J. Kim, A.A. Assadi, K. Hanna, Enhanced removal of antibiotics in hospital wastewater by Fe-ZnO activated persulfate oxidation, Environ. Sci.: Water Res. Technol. 5 (2019) 2193-2201. https://doi.org/10.1039/C9EW00611G.

[33] C. BROCHIER, E. DEFLIN, T. BRETING, ILLUMINATING COMPLEX - ALSTOM TRANSPORT SA, WO 2008/062141, 2008. 2 http://www.sumobrain.com/patents/wipo/Illuminatingcomplex/WO2008061789.html (accessed September 8, 2019).

[34] M.A. Hoque, M.I. Guzman, Photocatalytic Activity: Experimental Features to Report in Heterogeneous Photocatalysis, Materials. 11 (2018) 1990. https://doi.org/10.3390/ma11101990.

[35] W.A. Daoud, J.H. Xin, Y.-H. Zhang, Surface functionalization of cellulose fibers with titanium dioxide nanoparticles and their combined bactericidal activities, Surface Science. 599 (2005) 69-75. https://doi.org/10.1016/j.susc.2005.09.038.

[36] C. Indermühle, E. Puzenat, F. Dappozze, F. Simonet, L. Lamaa, L. Peruchon, C. Brochier, C. Guillard, Photocatalytic activity of titania deposited on luminous textiles for water treatment, Journal of Photochemistry and Photobiology A: Chemistry. $361 \quad$ (2018) 67-75. https://doi.org/10.1016/j.jphotochem.2018.04.047. 
[37] N.J. Peill, M.R. Hoffmann, Development and Optimization of a TiO2-Coated Fiber-Optic Cable Reactor: Photocatalytic Degradation of 4-Chlorophenol, Environ. Sci. Technol. 29 (1995) 2974-2981. https://doi.org/10.1021/es00012a013.

[38] R.-D. Sun, A. Nakajima, I. Watanabe, T. Watanabe, K. Hashimoto, TiO2-coated optical fiber bundles used as a photocatalytic filter for decomposition of gaseous organic compounds, Journal of Photochemistry and Photobiology A: Chemistry. $136 \quad$ (2000) 111-116. https://doi.org/10.1016/S1010-6030(00)00330-0.

[39] A review of intensification of photocatalytic processes, Chemical Engineering and Processing: Process Intensification. 46 (2007) 781-789. https://doi.org/10.1016/j.cep.2007.05.012.

[40] W. Choi, J.Y. Ko, H. Park, J.S. Chung, Investigation on TiO2-coated optical fibers for gas-phase photocatalytic oxidation of acetone, Applied Catalysis B: Environmental. 31 (2001) 209-220. https://doi.org/10.1016/S0926-3373(00)00281-2.

[41] P.-A. Bourgeois, E. Puzenat, L. Peruchon, F. Simonet, D. Chevalier, E. Deflin, C. Brochier, C. Guillard, Characterization of a new photocatalytic textile for formaldehyde removal from indoor air, Applied Catalysis B: Environmental. 128 (2012) 171-178. https://doi.org/10.1016/j.apcatb.2012.03.033.

[42] C.G. Hatchard, C.A. Parker, E.J. Bowen, A new sensitive chemical actinometer - II. Potassium ferrioxalate as a standard chemical actinometer, Proceedings of the Royal Society of London. Series A. Mathematical and Physical Sciences. $235 \quad$ (1956) 518-536. https://doi.org/10.1098/rspa.1956.0102.

[43] H. Yang, G. Li, T. An, Y. Gao, J. Fu, Photocatalytic degradation kinetics and mechanism of environmental pharmaceuticals in aqueous suspension of $\mathrm{TiO2:} \mathrm{A} \mathrm{case} \mathrm{of} \mathrm{sulfa} \mathrm{drugs,} \mathrm{Catalysis}$ Today. 153 (2010) 200-207. https://doi.org/10.1016/j.cattod.2010.02.068. 
[44] M.E. Leblebici, J. Rongé, J.A. Martens, G.D. Stefanidis, T. Van Gerven, Computational modelling of a photocatalytic UV-LED reactor with internal mass and photon transfer consideration, Chemical Engineering Journal. 264 (2015) 962-970. https://doi.org/10.1016/j.cej.2014.12.013.

[45] Z. Khuzwayo, E.M.N. Chirwa, Modelling and simulation of photocatalytic oxidation mechanism of chlorohalogenated substituted phenols in batch systems: Langmuir-Hinshelwood approach, Journal of Hazardous Materials. 300 (2015) 459-466. https://doi.org/10.1016/j.jhazmat.2015.07.034.

[46] M. Gar Alalm, A. Tawfik, S. Ookawara, Solar photocatalytic degradation of phenol by $\mathrm{TiO}_{2} / \mathrm{AC}$ prepared by temperature impregnation method, Desalination and Water Treatment. 57 (2016) 835844. https://doi.org/10.1080/19443994.2014.969319.

[47] J.E.A. Comer, 5.16 - Ionization Constants and Ionization Profiles, in: J.B. Taylor, D.J. Triggle (Eds.), Comprehensive Medicinal Chemistry II, Elsevier, Oxford, 2007: pp. 357-397. https://doi.org/10.1016/B0-08-045044-X/00133-4.

[48] H.-G. Guo, N.-Y. Gao, W.-H. Chu, L. Li, Y.-J. Zhang, J.-S. Gu, Y.-L. Gu, Photochemical degradation of ciprofloxacin in UV and UV/H2O2 process: kinetics, parameters, and products, Environ Sci Pollut Res. 20 (2013) 3202-3213. https://doi.org/10.1007/s11356-012-1229-x.

[49] Y. Qi, R. Qu, J. Liu, J. Chen, G. Al-Basher, N. Alsultan, Z. Wang, Z. Huo, Oxidation of flumequine in aqueous solution by UV-activated peroxymonosulfate: Kinetics, water matrix effects, degradation products and reaction pathways, Chemosphere. $237 \quad$ (2019) 124484. https://doi.org/10.1016/j.chemosphere.2019.124484.

[50] C. Sirtori, A. Zapata, W. Gernjak, S. Malato, A. Agüera, Photolysis of flumequine: Identification of the major phototransformation products and toxicity measures, Chemosphere. 88 (2012) 627-634. https://doi.org/10.1016/j.chemosphere.2012.03.047. 
[51] Y. Chen, K. Liu, Preparation and characterization of nitrogen-doped TiO2/diatomite integrated photocatalytic pellet for the adsorption-degradation of tetracycline hydrochloride using visible light, Chemical Engineering Journal. 302 (2016) 682-696. https://doi.org/10.1016/j.cej.2016.05.108.

[52] M. Dou, J. Wang, B. Gao, C. Xu, F. Yang, Photocatalytic difference of amoxicillin and cefotaxime under visible light by mesoporous g-C3N4: Mechanism, degradation pathway and DFT calculation, Chemical Engineering Journal. 383 (2020) 123134. https://doi.org/10.1016/j.cej.2019.123134.

[53] K.V. Kumar, K. Porkodi, F. Rocha, Langmuir-Hinshelwood kinetics - A theoretical study, Catalysis Communications. 9 (2008) 82-84. https://doi.org/10.1016/j.catcom.2007.05.019.

[54] H. Yang, G. Li, T. An, Y. Gao, J. Fu, Photocatalytic degradation kinetics and mechanism of environmental pharmaceuticals in aqueous suspension of TiO2: A case of sulfa drugs, Catalysis Today. 153 (2010) 200-207. https://doi.org/10.1016/j.cattod.2010.02.068.

[55] D. D, R. I, F. Z, X. Np, V. D, M. D, Degradation, mineralization and antibiotic inactivation of amoxicillin by UV-A/ $\mathrm{TiO}_{2}$ photocatalysis., J Environ Manage. $98 \quad$ (2012) 168-174. https://doi.org/10.1016/j.jenvman.2012.01.010.

[56] Z. Liu, X. Sheng, D. Wang, X. Feng, Efficient Hydrogen Peroxide Generation Utilizing Photocatalytic Oxygen Reduction at a Triphase Interface, IScience. 17 (2019) 67-73. https://doi.org/10.1016/j.isci.2019.06.023.

[57] H. Hayashi, S. Akamine, R. Ichiki, S. Kanazawa, Comparison of OH Radical Concentration Generated by Underwater Discharge Using Two Methods, (2016) 5.

[58] A.M. Díez, F.C. Moreira, B.A. Marinho, J.C.A. Espíndola, L.O. Paulista, M.A. Sanromán, M. Pazos, R.A.R. Boaventura, V.J.P. Vilar, A step forward in heterogeneous photocatalysis: Process intensification by using a static mixer as catalyst support, Chemical Engineering Journal. 343 (2018) 597-606. https://doi.org/10.1016/j.cej.2018.03.041. 
[59] J. Trawiński, R. Skibiński, Rapid degradation of clozapine by heterogeneous photocatalysis. Comparison with direct photolysis, kinetics, identification of transformation products and scavenger study, Science of The Total Environment. $665 \quad$ (2019) 557-567. https://doi.org/10.1016/j.scitotenv.2019.02.124.

[60] A Rabahi, AA Assadi, N Nasrallah, A Bouzaza, R Maachi, D Wolbert, Photocatalytic treatment of petroleum industry wastewater using recirculating annular reactor: comparison of experimental and modeling, Environmental Science and Pollution Research 26 (2019) 19035-19046.

[61] M Kamagate, AA Assadi, T Kone, S Giraudet, L Coulibaly, K Hanna, Use of laterite as a sustainable catalyst for removal of fluoroquinolone antibiotics from contaminated water, Chemosphere 195 (2018) $847-853$

[62] M. Paczkowska, M. Mizera, K. Lewandowska, M. Kozak, A. Miklaszewski, J. Cielecka-Piontek, Effects of inclusion of cetirizine hydrochloride in $\beta$-cyclodextrin, J Incl Phenom Macrocycl Chem. 91 (2018) 149-159. https://doi.org/10.1007/s10847-018-0808-y.

[63] F. Vargas, C. Rivas, Mechanistic Studies on Phototoxicity Induced by Antibacterial Quinolones, Toxic Substance Mechanisms. 16 (1997) 81-86. https://doi.org/10.1080/107691897229810.

[64] M.R. Eskandarian, H. Choi, M. Fazli, M.H. Rasoulifard, Effect of UV-LED wavelengths on direct photolytic and $\mathrm{TiO} 2$ photocatalytic degradation of emerging contaminants in water, Chemical Engineering Journal. 300 (2016) 414-422. https://doi.org/10.1016/j.cej.2016.05.049.

[65] I.T. Bujak, M.B. Kralj, D.S. Kosyakov, N.V. Ul'yanovskii, A.T. Lebedev, P. Trebše, Photolytic and photocatalytic degradation of doxazosin in aqueous solution, Science of The Total Environment. 740 (2020) 140131. https://doi.org/10.1016/j.scitotenv.2020.140131.

[66] A Abou Dalle, L Domergue, F Fourcade, AA Assadi, H Djelal, T Lendormi, Soutrel I., Taha S., Amrane A.,Efficiency of DMSO as hydroxyl radical probe in an Electrochemical Advanced Oxidation Process- 
Reactive oxygen species monitoring and impact of the current density, Electrochimica Acta 246 (2017) 1-8.

[67] K. Wang, J. Zhang, L. Lou, S. Yang, Y. Chen, UV or visible light induced photodegradation of AO7 on TiO2 particles: the influence of inorganic anions, Journal of Photochemistry and Photobiology A: Chemistry. 165 (2004) 201-207. https://doi.org/10.1016/j.jphotochem.2004.03.025.

[68] A.M. Dugandžić, A.V. Tomašević, M.M. Radišić, N.Ž. Šekuljica, D.ž. Mijin, S.D. Petrović, Effect of inorganic ions, photosensitisers and scavengers on the photocatalytic degradation of nicosulfuron, Journal of Photochemistry and Photobiology A: Chemistry. 336 (2017) 146-155. https://doi.org/10.1016/j.jphotochem.2016.12.031.

[69] W. Chen, J. Xu, S. Lu, W. Jiao, L. Wu, A.C. Chang, Fates and transport of PPCPs in soil receiving reclaimed water irrigation, Chemosphere. $93 \quad$ (2013) 2621-2630. https://doi.org/10.1016/j.chemosphere.2013.09.088.

[70] B. Chládková, E. Evgenidou, L. Kvítek, A. Panáček, R. Zbořil, P. Kovář, D. Lambropoulou, Adsorption and photocatalysis of nanocrystalline TiO2 particles for Reactive Red 195 removal: effect of humic acids, anions and scavengers, Environ Sci Pollut Res. 22 (2015) 16514-16524. https://doi.org/10.1007/s11356-015-4806-y.

[71] P.J.G. Henriksson, A. Rico, M. Troell, D.H. Klinger, A.H. Buschmann, S. Saksida, M.V. Chadag, W. Zhang, Unpacking factors influencing antimicrobial use in global aquaculture and their implication for management: a review from a systems perspective, Sustain Sci. 13 (2018) 1105-1120. https://doi.org/10.1007/s11625-017-0511-8.

[72] B. González-Gaya, L. Cherta, L. Nozal, A. Rico, An optimized sample treatment method for the determination of antibiotics in seawater, marine sediments and biological samples using LC-TOF/MS, Science of The Total Environment. $643 \quad$ (2018) 994-1004. https://doi.org/10.1016/j.scitotenv.2018.06.079. 
[73] L.M. Pastrana-Martínez, S. Morales-Torres, J.L. Figueiredo, J.L. Faria, A.M.T. Silva, Graphene oxide based ultrafiltration membranes for photocatalytic degradation of organic pollutants in salty water, Water Research. 77 (2015) 179-190. https://doi.org/10.1016/j.watres.2015.03.014.

[74] S. Yang, Y. Chen, L. Lou, X. Wu, Involvement of chloride anion in photocatalytic process, Journal of Environmental Sciences. 17 (2005) 761-765.

[75] R.W. Matthews, S.R. McEvoy, A comparison of $254 \mathrm{~nm}$ and $350 \mathrm{~nm}$ excitation of TiO2 in simple photocatalytic reactors, Journal of Photochemistry and Photobiology A: Chemistry. 66 (1992) 355366. https://doi.org/10.1016/1010-6030(92)80008-J.

[76] D.L. Liao, C.A. Badour, B.Q. Liao, Preparation of nanosized TiO2/ZnO composite catalyst and its photocatalytic activity for degradation of methyl orange, Journal of Photochemistry and Photobiology A: Chemistry. 194 (2008) 11-19. https://doi.org/10.1016/j.jphotochem.2007.07.008.

[77] M. Golshan, B. Kakavandi, M. Ahmadi, M. Azizi, Photocatalytic activation of peroxymonosulfate by TiO2 anchored on cupper ferrite (TiO2@CuFe2O4) into 2,4-D degradation: Process feasibility, mechanism and pathway, Journal of Hazardous Materials. 359 (2018) 325-337. https://doi.org/10.1016/j.jhazmat.2018.06.069.

[78] J. Li, M. Xu, G. Yao, B. Lai, Enhancement of the degradation of atrazine through CoFe2O4 activated peroxymonosulfate (PMS) process: Kinetic, degradation intermediates, and toxicity evaluation, Chemical Engineering Journal. 348 (2018) 1012-1024. https://doi.org/10.1016/j.cej.2018.05.032.

\section{Highlights}

- $\mathrm{TiO}_{2}$ on Luminous textile was tested for pharmaceutical compounds removal.

- Intensification of degradation efficiency was investigated with adding $\mathrm{H}_{2} \mathrm{O}_{2}$.

- $\mathrm{TiO}_{2}$ on Luminous textile showed better performances in the different water matrices 
- Even at pilot-scale, the light fabric showed a satisfactory stability and reusability. 